\title{
KEKHALIFAHAN ISIS DI ASIA TENGGARA, SEKADAR WACANA ATAU REALITAS?
}

\author{
The ISIS Caliphate in Southeast Asia, Is It Merely A Discourse or A Reality?
}

\author{
Poltak Partogi Nainggolan
}

\author{
Peneliti Utama Bidang Masalah Hubungan Internasional \\ Pada Pusat Penelitian Badan Keahlian DPR RI \\ Alamatemail: pptogin@yahoo.com
}

Naskah Diterima: 11 September 2017

Naskah Direvisi: 10 November 2017

Naskah Diterima: 22 November 2017

\begin{abstract}
ISIS weakening position in Syria and Iraq due to increasing military attacks and pressures of the US-led and the Russian, Iran and Al-Assad coalitions forces has pushed the formation of the ISIS Caliphate in Southeast Asia, as an option and new basis to continue its struggle for a formation of a global Islamic Caliphate. This research reveals whether an ISIS Caliphate in Southeast Asia is still a discourse or reality. Field research conducted one year, from May 2016 until mid-2017, with field observations in Indonesian border territories with South Philippines, namely Miangas, Sebatik and Nunukan, where the pro-ISIS Abu Sayyaf and other terrorist groups organize their attacks. Applying a qualitative method, the researcher conducted in-depth interviews with various experts, state apparatus, law enforcers, police and military officers. Research Findings disclose that An ISIS Caliphate in Southeast Asia is no longer a discourse, but it is a reality today, and continuing its struggle to form its global caliphate by waging war at its opponents --the nation states and their apparatus-- from inside and outside region.
\end{abstract}

Keywords: ISIS, Southeast Asia, caliphate, South Philippines, Foreign Terrorist Fighters, FTF's

\begin{abstract}
Abstrak
Melemahnya posisi ISIS di Suriah dan Irak akibat serangan militer koalisi Barat di pimpinan AS dan koalisi Rusia, Iran dan rezim Bashar al-Assad mendorong diciptakannya 'kekhalifahan jauh' ISIS di Asia Tenggara sebagai opsi dan basis baru perlawanan dan perjuangan khilafah global. Penelitian ini mengungkap apakah Kekhalifahan ISIS di Asia Tenggara baru sebatas wacana ataukah merupakan realitas. Penelitian lapangan dilakukan setahun, sejak April tahun 2016 sampai pertengahan tahun 2017, dengan observasi lapangan di kabupaten perbatasan terluar Indonesia, yaitu Miangas, Sebatik dan Nunukan, yang terhubung dengan wilayah Filipina Selatan dan aktivitas para pengikut ISIS, yakni Kelompok Abu Sayyaf dan lain-lain. Penelitian menggunakan pendekatan kualitatif, yang selain dengan studi kepustakaan, juga melakukan wawancara mendalam dengan para ahli, aparat penegak hukum dan anti-teroris, kepolisian serta militer. Hasil penelitian mengungkap kekhalifahan ISIS di Asia Tenggara tidak lagi sekadar wacana, tetapi tengah diperjuangkan dan dibangun, dengan memerangi negara-negara dan aparat penentangnya, baik dari dalam maupun luar kawasan.
\end{abstract}

Kata kunci: ISIS, Asia Tenggara, kekhalifahan, Filipina Selatan, Foreign Terrorist Fighters, FTF's

\section{PENDAHULUAN}

Kekhalifahan Islam ISIS (Islamic States in Iraq and Suriah) telah dideklarasikan pada tahun 2015 oleh Abu Bakr al-Baghdadi. Munculnya ISIS menjadi sangat fenomenal, karena dalam waktu singkat memperoleh pengikut, pendukung, dan simpatisannya yang menjamur di berbagai wilayah di dunia, melintasi batas negara, ras, etnik, pendidikan, kelas-sosial dan sub-nasional. Di samping itu, kehadiran ISIS membawa dampak pada terciptanya instabilitas keamanan di tingkat global, kawasan, dan negara nasional. Sebagai implikasinya, kehadiran ISIS mengancam tata dunia dan eksistensi negara 
bangsa modern yang ada, yang telah terbentuk pasca-Perjanjian Westphalia 1648 dan Perang Dunia II.

Ideologi khilafah yang disandang dan dikampanyekan secara luas oleh para pengikut, pendukung, dan simpatisannya secara cepat dapat menarik dukungan warga Muslim di berbagai belahan dunia. Perkembangannya melebihi keberhasilan perwujudan gerakan politik Pan-Islamisme di kawasan dan tingkat global dalam membangkitkan perlawanan bangsa-bangsa di wilayah jajahan dalam melawan imperialisme dan kolonialisme Barat di awal abad ke-20. Sesuai dengan namanya, pada awalnya Kekhalifahan Islam yang akan diwujudkan ISIS hanya meliputi wilayah Iraq dan Syaam (Suriah dan sekitarnya, yang disebut kawasan Levant), sehingga disebut juga dalam bahasa Arabnya sebagai al-Dawlah al-Islamiyah fii'I-Iraqi wa-sySyaam (Daesh). Karena itulah, ISIS di kalangan pengikutnya dideklarasikan sebagai Islamic States in Iraq and Levant (ISIL).

Sebelum menjadi ISIS dan ISIL, ia bermula dari organisasi Islamic State in Iraq (ISI) yang dibentuk pada 13 Oktober 2006 oleh Majelis Syura Mujahidin. Tokoh organisasi teroris AlQaeda di Iraq, yang bergabung tahun 1985, yang juga adalah perwira dinas keamanan Iraq yang telah dipecat karena sikap ekstrimismenya, Abu (Umar) Bakar al-Baghdadi, menggantikan posisi Zarkawi, pemimpin Al-Qaeda di Iraq sebelumnya. Al-Baghdadi kemudian dinobatkan sebagai Khalifah pertama ISI, yang kemudian berkembang menjadi ISIL/ISIS. ${ }^{1}$

Untuk memperoleh dukungan politik, sekaligus agama, yang luas dan kuat, tidak terbatas pada teritori negara tertentu, ISIS sering mengungkapkan eksistensinya sebagai Islamic State (IS). Dengan demikian, ISIS hendak dijadikan organisasi dan basis dari Kekhalifahan Islam sejagad (mondial), walaupun semula terbatas dan memfokuskan perjuangannya di Timur-Tengah, melanjutkan upaya perlawanan para penganut ideologi dan perlawanaan dari kelompok-kelompok Islam garis keras,

Muhammad Haidar Assad, ISIS: Organisasi Teroris Paling Mengerikan Abad Ini. (Jakarta: Zahira: 97, 2014), et seq. radikal, dan militan, melawan pendudukan dan dominasi kekuatan dan pengaruh Barat. ${ }^{2}$

ISIS adalah wujud perlawanan baru para aktor non-negara, yang memanfaatkan Islam sebagai pemersatu kepentingan dan dasar tujuannya. Kehadirannya menentang Barat dengan peradaban dan segala kepentingannya yang merugikan penduduk mayoritas di TimurTengah. ISIS hadir menawarkan ideologi, tujuan, dan peradaban alternatif. yang eksistensi dan aktivitasnya kemudian dinilai sangat mengancam tata dunia dan stabilitas keamanan yang ada, setelah surutnya pengaruh kelompok Al-Qaeda dan tewasnya pemimpin utamanya, Osama bin Laden, oleh operasi anti-terorisme AS.

Mengapa ISIS dinilai berbahaya dan mengancam tata dunia dan stabilitas keamanan global, di kawasan, dan banyak negara dewasa ini? Ini disebabkan oleh upayanya mencapai melalui aksi-aksi terorisme yang dilancarkannya, menjadikan siapapun target serangan, apakah laki-laki atau perempuan, orang dewasa atau anak-anak, muslim atau non-Muslim, dan seterusnya. Aksi-aksi terorisme para pengikut, pendukung atau simpatisan ISIS dilakukan secara berkelompok dan berjejaring ataupun seorang diri tanpa jejaring (lonewolf), secara membabi-buta dan tidak mengenal perikemanusiaan, baik secara sistematis maupun tidak, dengan jumlah korban yang sedikit maupun masif.

Sejak dideklarasikan pada Juni 2014, ISIS/IS telah melancarkan sebanyak 143 serangan terorisme, dengan berbagai macam modus operandi, di 29 negara, yang telah menewaskan paling sedikit 2.043 orang. ${ }^{3}$ Data memperlihatkan aksi-aksi terorisme ISIS di berbagai belahan dunia yang beragam pelaku, modus operandi, dan jumlah korbannya, yang kebanyakan dalam jumlah besar, yang tidak mengenal usia, jenis kelamin, dan kewarganegaraan, serta waktu serangannya. Serangan secara acak di mana dan kapan saja, dengan target korban yang besar, telah menebar

\footnotetext{
Assad, ISIS: 244.

“Teror Lintas Negara," Koran Tempo, 29 Mei 2017, 6.
} 
ketakutan pemerintah dan rakyat di berbagai negara.

Serangan terorisme secara langsung dan kontiniu oleh pelaku lama pengikut ISIS mantan petempur di Suriah dan Irak dan petempur asing (foreign terrorist fighters --FTFs) membuat pemerintah di berbagai negara kuatir atas ancaman dan aksi-aksi ISIS. Dalam waktu singkat, dengan kampanye radikalisasi ISIS melalui media massa daring, telah berhasil menarik dukungan secara cepat dan luas dari kalangan muda dan pendatang baru. Sampai pertengahan tahun 2016, di Suriah dan Irak, tempat ia dideklarasikan pembentukannya, ISIS meraih kemenangan dan sukses secara cepat. Direbutnya wilayah-wilayah stategis yang kaya dengan sumber minyak dan gas yang berperan penting dalam mendukung pembiayaan operasi militer ISIS membuat mereka harus beradaptasi dengan situasi baru, dengan merubah strategi perang mereka.

ISIS kemudian tidak lagi menjadikan Suriah dan Irak sebagai basis perjuangan, perlawanan dan kampanye terorisme internasional mereka. ${ }^{4}$ Perang, serangan, dan markas komando ISIS tidak lagi berpusat di Suriah dan Irak, tempat ISIS dideklarasikan, karena ISIS telah kehilangan banyak pengikut dan wilayah mereka, bersamaan dengan semakin menyusutnya secara drastis sumber-sumber pembiayaan perang dan wilayah operasional yang mereka duduki/kontrol setelah direbutnya kembali wilayah-wilayah yang kaya dengan minyak dan gas mereka oleh pihak Barat dan masing-masing rezim nasional yang mereka dukung. Sebagai konsekuensinya, ISIS harus memindahkan basis-basis operasi dan meningkatkan kehadiran mereka ke wilayah terdekat, antara lain ke wilayah lain Libya dan Afrika Barat dan Sahel, seperti Nigeria dan Burkina Faso. Sementara, ke wilayah Timur Jauh, untuk membedakannya dengan Timur Dekat atau Timur-Tengah, pemimpin ISIS di Suriah dan Irak melihat kawasan Asia Tenggara, sebagai alternatif.

Edith M. Leder, "ISIS on defensive in conflict areas but adapting: UN chief," The Jakarta Post, 8 February 2017, 12.
Keputusan ini harus diambil pemimpin ISIS di Suriah dan Irak untuk mencari dukungan baru dan memperkuat serangan mereka dalam mencapai tujuan akhir: mengimplementasikan khilafah untuk mewujudkan Kekhalifahan Islam, dengan aksi-aksi kekerasan dan terorisme mereka. Para pemimpin ISIS di bawah alBaghdadi pun memutuskan akan membangun 'Kekhalifahan Islam di Timur Jauh,' maksudnya Asia Tenggara, selain di tempat asalnya, untuk memperluas basis perlawanan. Pemimpin ISIS di Suraih dan Irak, selanjutnya, menyerukan kepada para pengikut, pendukung dan simpatisan mereka di berbagai belahan dunia untuk membangun dan melancarkan serangan dari wilayah asal mereka masing-masing sambil bekerjasama, melakukan komunikasi, dan menggunakan kontak dan jejaring dengan selsel lokal.

Dinamika perkembangan ISIS di atas memunculkan pertanyaan, apakah 'Kekhalifahan Asia Tenggara' ISIS memang benar-benar telah hadir, dan menjadi alternatif para pemimpin dan pengikut ISIS di kawasan ini untuk memperluas front dan melanjutkan perjuangan dan aksi-aksi terorisme internasional mereka? Penelitian ini bertujuan menjawab pertanyaan tersebut. Penulis memiliki tesis bahwa 'Kekhalifahan Asia Tenggara ISIS' terus dibangun sementara para pengikut ISIS melanjutkan aksi-aksi terorismenya, sehingga ia harus menghadapi tindakan kontra-terorisme negara-negara yang terancam di kawasan.

\section{PENELITIAN SEBELUMNYA}

Penelitian mengenai peran aktor nonnegara dalam aksi-aksi terorisme ISIS/IS di kawasan Asia Tenggara masih sedikit. Sebelum ini, studi dan penelitian mengenai peran para aktor non-negara dalam kaitannya dengan aksi-aksi terorisme Jamaah Islamiyah dan Al-Qaeda di Asia Tenggara sudah banyak dilakukan. Beberapa penelitian mengenai aksiaksi terorisme para aktor non-negara yang telah dilakukan oleh Kelompok Jamaah Islamiyah antara lain telah dipublikasikan dalam buku Daljit Singh, Terrorism in South and Southeast 
Asia in the Coming Decade, oleh lembaga riset Singapura, ISEAS.

Sedangkan publikasi yang mulai membicarakan ISIS telah muncul dalam karya Ansyaad Mbai, Dinamika Baru Jejaring Teror di Indonesia dan Keterkaitannya dengan Gerakan Radikalisme Transnasional, yang diterbitkan AS Production Indonesia. Kajiannya memang sangat memiliki keterbatasan, belum spesifik dan detil. Sedangkan yang jauh lebih komprehensif dan fokus adalah karya Muhammad Haidar Assad, yang tidak hanya mengupas mengenai asal-muasal ISIS, tetapi juga masuk dan berkembangnya ISIS di Indonesia. Namun demikian, pembahasannya masih dalam tahap perkembangan awal, sehingga diperlukan kajian yang lebih mendalam dan beragam mengenai perkembangan ISIS di Indonesia dan negara sekitar di kawasan Asia Tenggara, mengingat kawasan ini rawan menjadi target didirikannya basis baru mereka.

Hasil-hasil penelitian terkait dengan peran para aktor non-negara di kawasan Asia Tenggara yang telah dipublikasikan dalam jurnal ilmiah, antara lain, adalah karya Jones dan Smith. Riset mereka mendiskusikan secara mendalam dan fokus pada isu organisasi dan ideologi. ${ }^{5}$ Ada pula hasil-hasil riset tentang gerakan dan organisasi serta aktivitas jihad, yang terkini dalam hubungannya dengan eksistensi dan peran para aktor non-negara dalam ISIS/IS, tetapi masih terbatas datanya. Ini dapat dilihat pada, antara lain, karya-karya Ramakhrisna dan Thayer. ${ }^{6}$

Dalam publikasi jurnal, hasil-hasil penelitian setelah itu yang membahas ISIS/IS di Asia Tenggara adalah dalam karya Li Wei. ${ }^{7}$

Lihat, David Martin Jones and Smith, M L R, "Organization vs. Ideology: The Lessons from Southeast Asia," Current Trends in Islamist Ideology, Vol. 12 (Washington DC: Hudson Institute, 2012), 92-123.

6 Kumar Ramakrishna "Reflections of a Reformed Jihadist: The Story of Wan Min Wan Mat," Contemporary Southeast Asia: 38.3. Singapore (2016): 495-522; Carlyle A Thayer, "Southeast Asia's Regional Autonomy under Stress, Southeast Asian Affairs" (Singapore: ISEAS, 2016), 3-18. Li Wei. "Near ISIS Threat - Islamic State of Irap and alSham seeks to extend its presence to Central Asia and beyond," Beijing Review, Beijing (2015).
Namun, terlepas dari berbagai karya yang sudah ada ini, dibutuhkan penelitian yang lebih fokus dan lengkap, serta publikasinya secara lebih luas mengenai sepak-terjang dan perkembangan ISIS di Asia Tenggara, agar masyarakat dan para pembuat keputusan dapat memahaminya secara lebih baik lagi, sehingga dapat menyikapinya secara tepat. Sementara, publikasi terbaru dari Badan Nasional Penanggulangan Terorisme (BNPT), lebih bertujuan praktis untuk mengerem radikalisasi masyarakat secara cepat, sehingga masih perlu dilengkapi hasilhasil riset lainnya supaya hasil akhirnya dalam penanggulangan terorisme ISIS di Indonesia dan kawasan dapat lebih efektif. Penelitian yang terbaru mengenai perkembangan ISIS di kawasan adalah adalah karya Kumar.

Risetnya bersifat lebih komprehensif dan detil dalam membahas kelompok-kelompok pro-ISIS yang telah bermunculan di beberapa negara dan mendukung gagasan pembentukan sebuah 'Kekhalifahan ISIS di Asia Tenggara. ${ }^{8}$ Namun, anasilisnya terbatas pada data yang yang diperoleh pada tahun-tahun jauh sebelum hasil risetnya dipublikasikan. Perkembangan terkini yang genting di Filipina Selatan, khususnya Kota Marawi, belum masuk sebagai bagian risetnya.

\section{KERANGKA ANALISIS}

Gagasan penelitian ini berangkat dari muncul dan eksisnya para aktor non-negara sebagai baik itu pengikut, pendukung, simpatisan maupun pelaku aksi-aksi terorisme di lapangan. Dalam hal ini, para aktor nonnegara pelakunya menggunakan cara berpikir dan bersikap yang sangat fundamental dan konservatif, dan muncul dengan kampanye ideologi politik mereka yang mendompleng eksistensi agama untuk memobilisasi massa dan mencari justifikasi sekaligus pengikut. ${ }^{9}$ Peran

Kumar Ramakrishna S, "The Growth of ISIS Extremism in Southeast Asia: Its Ideological and Cognitive Featuresand Possible Policy Responses," New England Journal of Public Policy, Volume 29, Issue 1, Article 6, (Singapore: Nanyang Technological University 2017).

Daljit Singh, Terrorism in South and Southeast Asia in the Coming Decade. (Singapore: ISEAS 2009). 
mereka seringkali dikaitkan dengan kehadiran para pelaku terorisme asal berbagai negara, atau lintas-kewarganegaraan, yang bertujuan melakukan jihad melalui aksi-aksi terorisme yang mereka rencanakan dan lakukan di suatu wilayah negara. Mereka inilah yang kemudian populer memperoleh sebutan Foreign Terrorist Fighters (FTFs) dalam peristilahan terorisme dewasa ini. ${ }^{10}$

Di akhir dasawarsa 1980 dan awal dasawarsa 1990, Viotti dan Kauppi, telah menyebut aktor non-negara sebagai aktor non-pemerintahan atau non-governmental actors. ${ }^{11}$ Sedangkan di akhir dasawarsa 1990, Nicholson telah mengulanginya dengan penggunaan terminologi yang sama, selain telah mengawalinya dengan terminologi non-state actors. ${ }^{12}$ Kemajuan teknologi, khususnya teknologi komunikasi dan informasi, tidak hanya telah mendorong proses globalisasi secara lebih cepat dan luas, tetapi juga menciptakan kekuatiran terhadap lenyapnya identitas semula, untuk digantikan oleh identitas berbeda secara ekstrim dan berdaya hegemoni yang jauh lebih kuat.

Negara sendiri, secara realistis, semakin tidak berdaya menghadapi tekanan arus globalisasi yang kian cepat dan mengancam identitas lama ini. $^{13}$ Kegamangan dan kekuatiran terhadap pengaruh hegemoni baru yang berbeda secara ekstrim dan dirasakan sangat mengancam eksistensi mereka, telah membuat individu-individu mencari respons tersendiri secara lebih cepat daripada yang dapat diberikan negara selama ini. Dalam perjalanan sejarah dan konteks perkembangan

10 Lihat, Yonah Alexander and Dean Alexander, The Islamic State: Combating The Caliphate Without Borders. (London: Lexington Books, 2015).

11 Paul R. Viotti and Mark V. Kauppi, International Relations Theory: Realism, Pluralism, Globalism, Second Edition, Boston, (Massachusetts: Allyn and Bacon 1993), 7-8, 229-239.

12 Michael Nicholson, International Relations, (London: Macmillan Press Ltd, 1998).

13 Lihat, Jan Aart Scholte, "Global Capitalism and the State," International Affairs, Vol. 73, No. 3 (1997): 442; juga Ken Booth,"Security within Global Transformation," in Ken Booth (Ed.), Statecraft and Security: The Cold War and Beyond, Cambridge: Cambridge University Press: 338 355. dunia seperti inilah para aktor non-negara muncul sebagai teroris yang menimbulkan ancaman di berbagai tempat, negara, atau kawasan. Eksperimen khilafah sendiri bukanlah hal baru, karena pernah dicoba dan menemui kegagalan di masa lalu. Namun, marjinalisasi oleh sistem dunia akibat derasnya globalisasi dewasa ini melahirkan kekuatiran atas masa depan dunia yang sangat materialistik dan dikontrol kapitalisme dengan ideologi Baratnya, yang dinilai juga telah memakan korban dan meminggirkan komunitas Muslim dunia. ${ }^{14}$

Keterbelakangan, kemiskinan, dan ketimpangan global telah menjadi pemicu mudah munculnya aksi-aksi kekerasan yang dilakukan oleh para aktor non-negara di berbagai belahan dunia terhadap kelompok yang berbeda, terutama yang dalam kondisi perekonomian yang maju dan mempunyai kedudukan mapan secara politik. ${ }^{15}$ Sementara, langkanya akses kekuasaan dan ketimpangan kekuasaan (politik) akibat praktek otoriterisme yang berkepanjangan dan gagalnya proses transisi demokratis dan eksperimen demokrasi di berbagai negara, termasuk yang kaya Sumber Daya Alam (SDA) sekalipun, telah menguatkan keberpihakan kepada nilai lama, yang kemudian dijadikan ideologi penggerak sekaligus yang menjadi tujuan baru. Signifikannya pengaruh eksistensi dan peran para aktor non-negara ini telah berimplikasi pada terciptanya anarkisme atau kekacauan global (global disorder), ${ }^{16}$ yang sulit diatasi tanpa solusi global lewat kerja sama internasional (multilateralisme) baru untuk meresponsnya.

Aksi-aksi terorisme yang dilakukan oleh para aktor non-negara, telah menciptakan ketidakamanan di mana-mana. Akibat sifat ancaman asimetris yang diberikannya, yang sulit diantisipasi secara tepat, ia telah menghadirkan anarkisme yang meluas dan ketakutan global, karena sulitnya melakukan aksi pencegahan,

14 Lihat, John Gray, False Dawn: The Delusions of Global Capitalism, Granta, (1998).

15 Lihat, Robert Harvey, Global Disorder, (New York: Carroll $\&$ Graf Publishers, 2003).

16 Harvey, Global Disorder; juga, lihat kembali, Gray, False Dawn. 
apalagi secara sendiri-sendiri. Perkembangan situasi yang demikian ini telah membuat aksiaksi terorisme mengancam eksistensi dan masa depan baik negara bangsa pasca-Perjanjian Westphalia maupun negara majemuk yang terbentuk pasca-Perang Dunia II, termasuk hasil transisi demokratis Gelombang Ketiga. ${ }^{17}$

Aksi-aksi terorisme tidak hanya menciptakan ancaman keamanan terhadap keamanan individu, tetapi juga keamanan masyarakat, tidak hanya dalam skala nasional, tetapi juga regional dan global. Dalam perspektif ini, ancaman keamanan yang diakibatkan oleh aksi-aksi terorisme di tingkat individu menjangkau mulai tingkat lokal, negara dan bahkan ke kawasan sekitarnya. Barry Buzan, yang banyak membahas perkembangan masalah keamanan, terutama pasca-Perang Dingin, telah mengantisipasi munculnya ancaman ini di kawasan, termasuk yang disebabkan oleh kehadiran dan peran para aktor non-negara yang kemudian semakin dominan ini. ${ }^{18}$

Kekhalifahan Islam yang diperjuangkan ISIS dengan kekerasan terhadap siapa saja dan kelompok mana saja yang tidak mendukung atau menentangnya, termasuk dari kalangan internal Islam, tidak terlepas dari pengaruh sejarah dan Kekhalifahan Islam yang pernah ada, yakni masa pemerintahan Khulafaur Rasyidin, Daulah Ummayah, Daulah Abbasiyah, dan Daulah Ummayah di Cordoba, dan juga Kekhalifahan Utsmaniyah (Ottoman) diTurki. Dalam konteks ini, posisi dan kekuasaan kepala pemerintahan dan kepala agama tidak terpisahkan, di bawah penerapan Syariah. Tujuan kekhalifahan untuk mewujudkan dan menegakkan negara Islam tanpa mengenal batas wilayah negara/kerajaan, telah berkembang luas, dari yang semula hanya mengusir para tentara pendudukan Eropa dari jazirah Timur-Tengah. Oleh karena itu, luas wilayah pendudukan dan pengaruh ekspansi

17 Lihat, Samuel P. Huntington, The Third Wave: Democratization in the Late Twentieth Century, (Oklahoma: University of Oklahoma Press, Jan 1, 1993).

18 Barry Buzan, People, States $\mathcal{E}$ Fear: An Agenda for International Security Studies in the Post-Cold War Era, (The University of Michigan, Harvester Wheatsheaf, 1991).
Kekhalifahan Islam sampai ke Eropa Tenggara, termasuk Budapest (ibukota Hungaria), serta Afrika Utara dan Tanduk Afrika, termasuk Tunisia, Eritria, Jibouti dan Somalia, serta jazirah Asia Barat (Kaukasus).

Adapun Kekhalifahan Khulafaur Rasyidin berlangsung selama 29 tahun dari tahun 632 M-661 M di bawah pemerintahan 4 khalifah dengan wilayah kekuasaan di Mekkah dan Madinah, Arab Saudi. Kekhalifahan Ummayah berlangsung lebih lama, dari tahun 661 M-750 M, dengan pemerintahan 14 khalifah dan berpusat di Damaskus, Suriah sekarang. Kemudian, Kekhalifahan Daulah Abbasiyah berlangsung dalam masa jauh lebih lama, mulai tahun $750 \mathrm{M}-1.258 \mathrm{M}$, di bawah pemerintahan 37 khalifah, yang berpusat di Baghdad, Irak dewasa ini. Sejarah Kekhalifahan Islam juga tidak dapat dilepaskan dari perjalanan kekhalifahan yang pernah didirikan di Dunia Barat oleh Daulah Ummayah di Cordoba, Andalusia, Spanyol, dari tahun 750 M-1031 M, serta juga Utsmaniyah (Ottoman), Turki, yang berlangsung dari tahun $1453 \mathrm{M}-1922 \mathrm{M}$. Kecuali Kekhalifahan Khulafaur Rasyidin yang lebih kecil yang dipilih dan dijalankan melalui proses permusyawaratan, Kekhalifahan Islam selanjutnya didominasi pertarungan kekuasaan dan kekerasan dalam suasana konflik internal dan tantangan kekuatan eksternal non-Islam (Barat), yang berjalan di bawah sistem monarki, dengan kekuasaan pemimpin (khalifah)-nya diwariskan secara turun-temurun dan bersifat eksklusif. ${ }^{19}$

Sementara itu, para pengikut, pendukung dan simpatisan ISIS/IS Malaysia, Indonesia dan Filipina di Suriah dan Irak menggunakan nama dan bendera "Khatibah Nusantara." ${ }^{20}$ Keputusan ini dibuat sebagai upaya para tokoh ISIS/IS asal Indonesia, antara lain, Bahrum Syah dan Rosikien Nur, untuk mencari pengikut, pendukung, dan simpatisan baru di Indonesia dan Malaysia, yang berbahasa Melayu. Karena, di luar kawasan ini, banyak pe-jihad ISIS/IS menggunakan

\footnotetext{
19 Lihat, Faisal Ismail,"Khilafah dalam Perspektif Sejarah," Koran Sindo, 8 Mei 2017, 6.

20 “Jurnal Malam”, Berita Satu, 16 Desember 2015, 22.21.
} 
Inggris dan Arab, dalam komunikasi mereka. ${ }^{21}$ Di tahun 2014 lalu, para pengikut Khatibah Nusantara telah menyatakan kesetiaannya kepada Pemimpin ISIS/IS di pusat, Abu Bakr al-Baghdadi, sebagai Kholifah Almuslimin, lewat facebook. $^{22}$ Kematian pemimpin, perancang operasi dan komandan lapangan AL-Qaeda, masing-masing Osama bin Laden dan Anwar alAwlaqi pada tahun 2011, serta Abu Musab alZarkawi, jauh lebih awal pada tahun 2006, serta aksi-aksi terorisme internasional yang dilakukan organisasi dan para penerusnya, yakni ISIS/ IS, tidak bergantung pada perintah pemimpin tertinggi atau tokoh sentral mereka. ${ }^{23}$

\section{METODOLOGI}

Penelitian ini bersifat deskriptif-analitik, mengungkap dan menganalisis masalah, dengan mengombinasikan penelitian kepustakaan dan lapangan. Penelitian kepustakaan dilakukan di Jakarta dan daerah-daerah yang dikunjungi. Sedangkan penelitian lapangan dilakukan pada April-Mei 2016 di perbatasan perairan Indonesia dengan Filipina di Kabupaten Kepulauan Talaud, terutama Kecamatan Pulau Miangas pada Juni 2017, yang berbatasan langsung dengan perairan Filipina Selatan. Penelitian lapangan kedua dilaksanakan di perbatasan darat Indonesia dengan Malaysia di sekitar Provinsi Kalimantan Utara atau perbatasan perairan Indonesia dengan Malaysia di Kabupaten Nunukan dan Pulau Sebatik Provinsi Kalimantan Utara, yang menyediakan akses langsung dari wilayah darat dan perairan menuju wilayah Filipina Selatan. Wilayah ini tengah bergolak akibat pertempuran antara Kelompok Abu Sayyaf, Maute dan lain-lain yang pro-ISIS/IS, yang berupaya merebut Kota Marawi, melawan militer Pemerintah Filipina.

\footnotetext{
21 Lihat, Zakir Hussain and Shannon Teoh,"IS fighters from M'sia, RI form military unit," The Jakarta Post, 27 September 2014, 3.

22 Keterangan Kepala Polisi Kerajaan Malaysia, Khalid Abu Bakar, lihat Fedina S. Sundaryani and Tama Salim,"Alleged Indonesian IS recruiter arrested in Malaysia," The Jakarta Post, 7 Desember 2015, 4.

23 Lihat, Ikhwanul Kiram Mashuri,"Kesalahan Diagnosis yang Melahirkan ISIS," Republika, 7 Desember 2015, 9.
}

Adapun penelitian kepustakaan, sebagai penelitian awal, dilakukan mulai permulaan Januari 2016, sedangan penelitian lapangan untuk wawancara secara mendalam dijalankan pada April 2016-Juni 2017. Pengumpulan data dilakukan melalui studi kepustakaan dan media massa, baik cetak maupun elektronik dan daring. Selanjutnya, pengumpulan data dilanjutkan dengan kegiatan penelitian dan observasi lapangan. Langkah berikutnya adalah wawancara secara mendalam dengan aparat kepolisian dan militer Polres dan Polsek, Korem, Kodim, dan Koramil, Lanal dan Posal, pasukan Pengamanan Perbatasan (Pamtas), pasukan nonorganik Brimob dari Polda, serta Bupati dan Camat, yang tugas mereka juga terkait dengan pembinaan dan pengawasan pemerintahan, serta keamanan dalam negeri, termasuk masalah intelijen daerah. Secara khusus, melalui wawancara ditanyakan pendapat, melalui wawancara, pengamat teroris internasional dan Direktur The Institute for Policy Analysis and Conflict (IPAC), Sidney Jones, dan Nasir Abbas, mantan pengikut JI, yang pernah memimpin JI untuk kawasan Asia Tenggara. Kegiatan pengamatan langsung di lapangan (observasi) melalui kunjungan ke kawasan perbatasan darat dan perairan negara-negara di sekitar wilayah Filipina Selatan melengkapi pengumpulan data yang telah dijalankan melalui wawancara secara mendalam.

Proses analisis data didahului dengan tahapan seleksi dan konfirmasi data. Data yang terseleksi dan valid ini kemudian digunakan untuk ditriangulasikan dan dianalisis secara mendalam dan kritis. Kegiatan triangulasi data dilakukan dalam perspektif metode dan sumber datanya. Di sini data hasil studi kepustakaan, pengamatan lapangan dan yang diperoleh dari wawancara mendalam dilihat validitas dan relevansinya untuk menjawab pertanyaanpertanyaan penelitian. Data yang diperoleh dianalisis memakai referensi dan kerangka pemikiran mengenai peran para aktor non-negara dalam hubungan internasional. Baik aktivitas pengumpulan maupun analisis data dalam penelitian ini, keduanya secara menyeluruh menggunakan pendekatan kualitatif. 


\section{SIAPA KEKHALIFAHAN ISIS ASIA TENGGARA?}

Wilayah Asia Tenggara mencakup paling sedikit 10 negara cukup luas. Dengan melihat sejarah penyebaran dan perkembangan Islam selama berabad-abad dan aktivitas penduduk Muslimnya belakangan ini, wilayah Filipina Selatan menjadi tempat yang subur untuk tumbuh dan berkembangnya ISIS/IS sebagai basis gerakan perlawanan pan-Islamisme di Asia Tenggara. Kondisi geografis yang ada jelas sangat mendukung. Dengan Indonesia, kedua negara memiliki sekitar 25.000 pulau, yang dibatasi oleh perairan yang amat luas dan sulit dari jangkauan kontrol patroli maritim aparat keamanan kedua negara. ${ }^{24}$ Ditambah dengan Malaysia, pulau-pulau dan wilayah perairan yang potensial untuk dijadikan pusat aktivitas 'Kekhalifahan Islam Asia Tenggara' semakin luas dan sulit dikontrol aparat keamanan ketiga negara, termasuk di perbatasan perairan. Ini terungkap dalam in-depth interviews dengan aparat pertahanan-keamanan di lapangan..$^{25}$

Dalam konteks geografis, terminologi 'Kekhalifahan Asia Tenggara' tidak berbeda jauh cakupan luas wilayahnya dengan terminologi yang semula diintroduksi, yakni 'Kekhalifahan Asia Timur,' dengan memasukkan Jepang yang juga sebagai target sasaran ISIS. Yang penting, penduduk di wilayah itu akan tunduk dan membayar pajak (jizyah) pada pemimpin sentral ISIS, Abu Bakr al-Baghdadi. Sedangkan para pengikut, pendukung dan simpatisannya meliputi jihadists, dari negara-negara anggota ASEAN, kelompok etnik Uighurs China, Arab dan Afrika.

Jika aparat keamanan negara-negara di kawasan, terutama dalam lingkup ASEAN, dewasa ini telah melihat kehadiran Kekhalifahan ISIS/IS di kawasan Asia Tenggara, analis konflik

\footnotetext{
24 Wawancara dengan Kol. Laut (Pelaut) A.M. Susanto, SW, Asisten Operasi Lantamal VIII, dan juga wawancara dengan Kol. Laut (Pelaut) Ivong Wibowo, Asisten Intelijen Lantamal VII pada 11 Mei 2016 di Kota Manado. 25 Wawancara dengan Kol. Laut (Pelaut) A.M. Susanto, SW, Juga dalam wawancara dengan Kol. Laut (Pelaut) Ivong Wibowo, Asisten Intelijen Lantamal VII, dan dengan Letkol Laut (KH) F.V. Yakobus, Danlanal Kabupaten Talaud pada 11 Mei 2016 di Kabupaten Melonguane.
}

dan terorisme internasional, Sidney Jones, pada awalnya berpendapat kekhalifahan ISIS/ IS tersebut tidak ada. Adapun yang tengah diwujudkan ini bukanlah kekhalifahan baru, melainkan realisasi cita-cita dan perjuangan Jamaah Islamiyah (JI) dan penerusnya, yang tetap berpusat di Indonesia dan Malaysia. Adapun wilayah mashriq (wilayah timur) Daulah Islamiyah yang dulu direncanakan di Filipina Selatan, dalam penilaian Jones, gagal dibentuk. ${ }^{26}$

Pertama-tama tentu saja harus dipahami bahwa ISIS/IS merupakan organisasi bawah tanah (clandestine) atau tandzim siri, yang aktivitas dan operasi terorismenya bersifat sangat tertutup atau rahasia. Para pengikut dan aktor terorismenya pun mengisolasikan diri mereka dari masyarakat. ${ }^{27}$ Paling tidak terdapat beberapa kelompok Islam konservatif atau radikal di setiap negara di kawasan Asia Tenggara, yang mendukung cita-cita ISIS/IS di pusat, tempat ISIS/IS lahir atau berasal, yakni di negara-negara Timur-Tengah. Cita-cita tersebut adalah terwujudnya khilafah global melalui perjuangan jihad dengan kekerasan dan menghalalkan segala macam cara, termasuk pembunuhan terhadap kalangan Muslim sendiri, selain kalangan non-Muslim, termasuk perempuan dan anak-anak..$^{28}$ Jadi, walaupun perjuangan menegakkan khilafah di Malaysia, Singapura dan Indonesia, dilakukan masing-masing kelompok, namun mereka tetap memiliki komunikasi dengan pusatnya di Suriah dan negara Timur-Tengah lainnya, ataupun Filipina Selatan..$^{29}$ Sehingga, selalu saja

\footnotetext{
26 Wawancara dengan Sidney Jones, analis keamanan dan terorisme internasional, Direktur The Institute for Policy and Analysis of Conflict (IPAC) pada 4 April 2016; juga dalam penjelasan Sidney Jones atas pertanyaan tertulis, disampaikan pada 26 April 2017.

27 Wawancara dengan Kompol Malsukri, Kasubbag Produk Bagian Analisa Ditintelpam Polda Sulawesi Tengah pada 24 Mei 2016 di Palu.

28 Wawancara dengan 2 perwira Densus 88, Anggota Tim Pemerintah yang menghadiri Pembahasan Amandemen RUU Tindak-Pidana Terorisme pada 30 Maret 2017 di Jakarta.

29 Wawancara dengan Sidney Jones, analis keamanan dan terorisme internasional, Direktur The Institute for Policy and Analysis of Conflict (IPAC) pada 4 April 2016; juga dalam penjelasan Sidney Jones atas pertanyaan tertulis, disampaikan pada 26 April 2017.
} 
ditemukan Warga Negara Indonesia, Malaysia, atau lainnya sebagai FTFs, dalam serangan terorisme pro-ISIS/IS di Indonesia, Filipina, dan lain-lain.

Indonesia sendiri telah dijadikannya sebagai salah satu dari empat negara sasaran serangan ISIS/IS untuk persiapaan pembentukan kekhalifahannya di Asia Tenggara. ${ }^{30}$ Karena itulah, Kapolri Badrodin Haiti dan Kepala BIN Sutiyoso melanjutkan status Siaga I di bulan Desember 2015, pasca-pelaksanaan Pilkada serentak. Setelah Aman (Oman) Abdurrahman, pemimpin ISIS Nusantara (Indonesia), pendiri Jamaah Ansharut Daulah (JAD), ditahan oleh aparat keamanan Indonesia akibat aksi-aksi terorismenya yang panjang sejak tahun 2003, pimpinan aktivitas terorisme pro-ISIS/ IS diambil alih kaum muda. ${ }^{31}$

Abu Jandal, tokoh JAD Malang, Jawa Timur, yang tewas di Suriah pada tahun 2016, sebagai contoh, adalah penghubung ISIS di Suriah dan sekaligus petinggi ISIS/IS di Indonesia, bersamasama Santoso, tokoh Mujahidin Indonesia Timur (MIT), yang tewas di Poso Juli 2016. Bachrumsyah, petinggi JAD Jabodetabek yang tewas di Suriah pada awal 2017, memainkan peran sebagai agitator ISIS/IS Asia Tenggara. Lalu, Bachrun Naim alias Anggih Tamtomo, alias Abu Rayan, yang juga murid Aman (Oman) Abdurrahman, yang telah 'hijrah' ke Suriah sejak Mei 2014 untuk bergabung dengan ISIS/IS, juga merupakan salah satu tokoh ISIS/ IS Asia Tenggara. ${ }^{32}$ Kepemimpinan pengikut ISIS/IS asal Indonesia, seperti Abu Jandal alias Salim Mubarak At-Tamimi, ${ }^{33}$ Bachrum Syah,

30 Laporan intelijen Uni Emirat Arab, diungkapkan oleh Kapolri Badrodin Haiti dan Kepala BIN, Sutiyoso. Lihat, Mitra Tarigan,"TNI Waspadai Ancaman ISIS," Koran Tempo, 10 Nopember 2016, 9

31 Wawancara dengan Sidney Jones, analis keamanan dan terorisme internasional, Direktur The Institute for Policy and Analysis of Conflict (IPAC) pada 4 April 2016; juga dalam penjelasan Sidney Jones atas pertanyaan tertulis, disampaikan pada 26 April 2017.

32 Jejaring ISIS di Kampung Melayu," Majalah Tempo, 29 Mei-4 Juni 2017, 367-37.

33 Ia, dan juga Bachrum Syah dilaporkan tewas akibat serangan udara koalisi militer AS dan Pemerintah Irak atas basis pertahanan ISIS/IS di Mosul, Irak, lihat, Mitra Tarigan,"TNI Waspadai Ancaman ISIS," Koran Tempo, 10 Nopember 2016, 9. dan belakangan Bahrum Na'im, diakui dan cukup berpengaruh dalam aktivitas ISIS/IS di Suriah, sehingga orang Indonesia telah menjadi pemimpin pasukan tempur asing (FTFs) yang disegani di sana. ${ }^{34}$ Ketiga orang itu tengah berebut menjadi yang terbesar pengaruhnya dan diakui sebagai pemimpin ISIS/IS tidak hanya di Indonesia, tetapi juga kawasan yang lebih luas, yaitu di Asia (Tenggara). ${ }^{35}$

Di Filipina (Selatan), pemimpin Kelompok Abu Sayyaf, Isnilon Totoni Hapilon, menunjukkan sepak terjangnya yang semakin berskala internasional, dengan aksi-aksi penculikan dan pembajakan kapal di perbatasan perairan Filipina Selatan dengan Sabah, Sulu, dan Indonesia, yang juga telah menjadikan Anak Buah Kapal (ABK) Warga Negara Indonesia (WNI) sebagai sasarannya. Kelompok Abu Sayyaf belakangan ini semakin mengontrol kawasan perairan yang berbatasan dengan Malaysia, serta Indonesia di wilayah Provinsi Sulawesi Utara, yang memiliki pulau-pulau kecil terluar, di Kabupaten Sangir dan Kabupaten Talaud. Karena itulah, aksi-aksi pembajakan kapal dan penyanderaan awaknya, dengan meminta tebusan, yang dilakukan para pengikut kelompok itu terus meningkat belakangan paling sedikit di tiga negara, yakni Malaysia-Filipina-Indonesia. ${ }^{36}$

Aksi-aksi Kelompok Abu Sayyaf dalam pembajakan kapal dan penyanderaan Anak Buah Kapal (ABK) juga telah memasuki daratan Malaysia, terutama negara bagian Sabah, yang dapat digunakan aksesnya ke wilayah perairan Filipina Selatan melalui perairan Laut Sulu ke Tawi-Tawi dan lain-lain. ${ }^{37}$ Di Malaysia telah terdapat paling sedikit 7 kelompok pro-ISIS, yakni Tandzim Al Qaeda Malaysia (dibentuk Yazid Sufaat), Briged Khalid Al-Walid, Darul Islam Malizia/DIM (dibentuk mantan dosen Universitas

\footnotetext{
34 Wawancara dengan Sidney Jones, analis keamanan dan terorisme internasional, Direktur The Institute for Policy and Analysis of Conflict (IPAC) pada 4 April 2016; juga dalam penjelasan Sidney Jones atas pertanyaan tertulis, disampaikan pada 26 April 2017.

Ibid.

Wawancara dengan Kol. Laut (Pelaut) A.M. Susanto, SW.

Ibid.
} 
Malaya, Dr. Mahmud Ahmad), Briged Darul Islamiyah, Arakan Daulah Islamiyah, Fisabilillah, dan Daulah Islamiyah Malaysia. ${ }^{38}$ Pada 14 Nopember 2016, intelektual Malaysia yang pernah dilatih Al-Qaeda di Afghanistan pada akhir tahun 1990-an, yakni Dr. Mahmud Ahmad, kemudian lebih banyak melakukan operasinya di Filipina Selatan.

Dr. Mahmud Ahmad alias Abu Handzalah diidentifikasi sebagai pengikut ISIS/IS yang merencanakan untuk membentuk blok teror ISIS/IS yang lebih besar di Asia Tenggara, yang akan menyatukan sel-sel teror pro-ISIS di Malaysia, Indonesia dan Filipina. Sebelumnya, ia telah menggagas pertemuan para tokoh militan di kawasan untuk membentuk Daulah Islamiyah Asia Tenggara. Ia aktif melakukan aksi-aksi terorisnya bersama Kelompok Abu Sayyaf di Filipina Selatan, dan, di antaranya, terlibat dalam serangan-serangan bom ke tentara Filipina. ${ }^{39}$

Beberapa pengikut ISIS di Malaysia telah merencanakan aksi serangan ke tokoh-tokoh penting (Very Important Persons --VIPs) di sana. Mereka memiliki komunikasi dengan para anggota senior ISIS di Suriah dan Eropa, dan telah menerima perintah untuk melakukan serangan atas kepentingan Barat di Kuala Lumpur dan tempat-tempat hiburan di Klang Valley. ${ }^{40}$ Pengikut ISIS lainnya di Malaysia ditengarai mengumpulkan dana untuk melancarkan serangan di dalam negeri, selain sebelumnya telah mengumpulkan dana untuk membantu mereka yang akan ke Suriah dan membantu mereka yang akan kembali dan melanjutkan aksi-aksinya di Malaysia. ${ }^{41}$ Orang dekat Dr. Mahmud Ahmad, yakni Mohamad Najib Hussein alias Abu Anas, pada 17 Desember 2105 tewas oleh militer Filipina di Basilan.

Jones, dalam laporan terkininya, "Marawi, the 'East Asia Wilayah,' and Indonesia,"

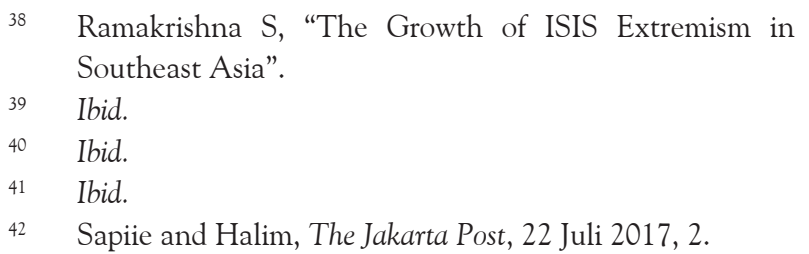

telah beralih pikiran dan begitu serius melihat kemungkinan aksi-aksi terorisme baru para pengikut ISIS/IS di kota-kota di Indonesia dan Malaysia, meniru apa yang dilakukan oleh rekan-rekan mereka di Filipina, dengan serangan ke Kota Marawi. Para pemimpin ISIS/IS di pusat (Timur-Tengah), dengan jatuhnya basis mereka belakangan di Mosul, Irak, dan juga sebelumnya di Suriah, juga akan mendorong mereka yang kembali ke negaranegara di kawasan Asia Tenggara, terutama Indonesia, bersama rekan-rekan mereka dari berbagai negara (FTFs), untuk melakukan aksi terorisme yang sama spektakulernya seperti di Kota Marawi.

\section{DIMANA KEKHALIFAHAN ISIS ASIA TENGGARA?}

Wilayah Filipina Selatan, dengan Mindanao sebagai pusatnya, adalah cikal-bakal basis Kekhalifahan ISIS di Asia Tenggara. Setelah jatuhnya secara menyeluruh Kota Mosul di Irak pada Juli 2017 dari tangan ISIS/IS ke pasukan Irak yang didukung pasukan koalisi Barat, upaya membangun 'Kekhalifahankekhalifahan Provinsi' menjadi pilihan tidak terelakkan. Opsinya kini tidak hanya di Afrika Barat (Nigeria) dan Mesir yang masing-masing sudah memilki kekuatan dengan Boko Haram dan Anasr Beit al-Maqdis, tetapi juga Filipina Selatan. ${ }^{43}$ Kawasan ini telah memiliki kelompok pro-ISIS/IS yang jauh lebih independen dalam operasi mereka selama ini, dan juga beragam pengikutnya, yakni Abu Sayyaf, BIFF, AKF dan Maute, yang membuat 'kekhalifahan jauh' ini sama potensialnya dalam melanjutkan operasi ISIS/IS di Timur Jauh (Asia).

Wilayah Filipina Selatan adalah tempat yang tengah dikembangkan sebagai basis ISIS di Asia Tenggara, karena di sana terdapat Kelompok Abu Sayyaf dan lain-lain yang selama ini mengontrol stabilitas keamanan di wilayah tersebut. Di wilayah tersebut telah dibangun kekuatan dan basis militer para pengikut ISIS tidak hanya dari Kelompok

$43 \quad$ Yaroslav Trofimov,"After Mosul, Faraway ISIS 'Provinces' Fight On," The Wall Street Journal, 21-23 Juli, 2017, A2. 
Abu Sayyaf, tetapi juga para pendukungnya asal negara sekitar, termasuk Bangladesh, dengan kekuatan sekitar 4 batalyon. Batalyon 1 didukung oleh para pengikut ISIS di Malaysia, Batalyon 2 dan 3 dari terutama Filipina, dan Batalyon 4 dari Indonesia. ${ }^{44}$ Semua batalyon ini melibatkan pengikut/pendukung ISIS dari negara lain (FTFs). Para pengikut ISIS ini mendapat perintah langsung dari Bachrum Naim untuk mengembangkan kawasan itu sebagai basis perlawanan baru ISIS. ${ }^{45}$ Dalam operasinya, mereka menyerang (markas) polisi, orang asing warga negara Barat, menahan sandera untuk meminta tebusan uang, dan meminta pembebasan teman-teman mereka pengikut ISIS yang tengah ditahan aparat keamanan, seperti di Filipina dan Indonesia. Beberapa tahanan di kedua negara itu berhasil dipengaruhi dan berbaiat menjadi pengikut ISIS dan pelaku aksi-aksi terorisme.

Adapun Mindanao, secara geografis, letaknya terpisah dari bagian kepulauan di Filipina lainnya. Sebagai kepulauan yang terletak di selatan, Mindanao berpenduduk 22 juta orang sebagai mayoritas Muslim, dari keseluruhan penduduk negeri dengan mayoritas Katholik itu, yang tinggal di sana. Mindanao memiliki jumlah penduduk hidup di bawah garis kemiskinan terbesar dari seluruh wilayah Filipina, yakni 53,7 persen, dari total 21,6 persen penduduk negara Filipina hidup di bawah garis kemiskinan. Hidup dengan keterbelakangan dan kondisi tanpa hukum yang jelas di sebagian besar wilayah mereka, telah melatarbelakangi mengapa dewasa ini wilayah Mindanao dan Bangsa Moro tetap hidup dalam konflk vertikal dan horizontal, walaupun telah

44 Keterangan Direktur Pencegahan BNPT, Brigjen Pol. Hamidin, dan pengamat terorisme, Al-Chaidar, dalam "Wawancara Teror Bom di Bandung," Kompas Malam, Kompas TV, pada 28 Februari 2017: 21.08; Juga, wawancara dengan Nasir Abbas, mantan Ketua Mantili III JI, pasca-FGD tentang amandemen RUU Tindak Pidana Terorisme dan Penanganan Korban pada 4 Nopember 2016 di Banten.

45 Keterangan Direktur Pencegahan BNPT, Brigjen Pol Hamidin, dan pengamat terorisme, Al-Chaidar, dalam "Wawancara Teror Bom di Bandung," Kompas Malam, Kompas TV, pada 28 Februari 2017, 21.08 diberi otonomi. ${ }^{46}$ Adapun sel-sel ISIS/IS di Filipina (Selatan) cepat marak berkembang tidak semata karena hebatnya pengaruh ISIS/IS di Suriah dan Irak, tetapi juga oleh runtuhnya proses perdamaian yang telah diinisiasi Benigno S. Aquino III di tahun 2015, yang menghadapi jalan buntu di masa pemerintahan sesudahnya di bawah Duterte, karena ia hanya fokus pada perang melawan (mafia) narkoba. ${ }^{47}$

Wilayah Filipina Selatan, yang telah selama beberapa abad didiami bangsa Moro yang mayoritas Muslim, terus bergolak sejak kekuasaan Spanyol, AS, Jepang hingga Manila dewasa ini. Sejak pemberontakan di dasawarsa 1970, bahkan setelah Nur Misuari dan gerakan pembebasannya (Moro National Liberation Front) memperoleh kekuasaan otonomi atas wilayah tersebut, Mindanao tetap merupakan basis perjuangan kalangan ekstrimis Muslim, termasuk kaum militan dari Indonesia, Malaysia, dan negara-negara lain, untuk melarikan diri dan mengikuti pelatihan militer di hutanhutan di sana. ${ }^{48}$ Osama bin Laden, Pemimpin Al-Qaeda, memiliki kontak reguler dengan Hashim Salamat, pemimpin separatis Muslim di Mindanao, yang telah tewas. Sedangkan arsitek serangan terorisme 9/11 2001 ke AS, Khalid Sheikh Mohammed, telah merencanakan serangan pada Paus Johannes Paulus II di Manila pada tahun 1990-an dan terus berkampanye melawan dukungan AS pada Pemerintah Filipina, seperti disampaikannya dalam surat kepada Presiden Obama dari tahanannya di Guantanamo. ${ }^{49}$

Perbatasan perairan yang panjang dan luas, dan langka pos pengawasan imigrasi, telah membuat wilayah Filipina Selatan sebagai kawasan yang ideal sebagai tujuan pelarian dan sekaligus basis perlawanan para aktor nonnegara, ekstrimis asing (FTFs) dan teroris pro-

\footnotetext{
46 Jake Waxwell Watts, "Philippines Stumbles in War on Militants," The Wall Street Journal, 2-4, Juni 2017, A3.

47 Richard C. Paddock, "Duterte ignored rise of ISIS," The New York Times International Edition, 13 Juni 2017, 6.

48 Richard C. Paddock, "Influence of ISIS in Southeast Asia attacks," The New York Times International Edition, 29 Mei 2017, 8 .

49 James Hookway,"ISIS Sinks Teeth into Philippines," The Wall Street Journal, 15 Juni 2017, A5.
} 
ISIS di Asia Tenggara..$^{50}$ Para petempur ISIS/ IS telah membangun dan memiliki jejaring yang luas di kawasan ini. Dengan aktivitas jejaringnya yang canggih dan sumber daya yang banyak yang mereka miliki, kawasan ini menjadi menarik buat mereka untuk didatangi. ${ }^{51}$

Selama beberapa dasawarsa, wilayah Filipina Selatan tidak dapat dikontrol sepenuhnya oleh Pemerintah Filipina, terutama dari segi keamanan, sehingga wilayah itu dipenuhi konflik dan aksi-aksi bersenjata, kekerasan dan kriminal dari kelompok separatis dan radikal keagamaan, seperti MNLF, MILF, Abu Sayyaf, Maute dan lain-lain. Jadi, selain Kelompok Maute, selama ini di Filipina Selatan telah terdapat kelompokkelompok pemberontak, termasuk Kelompok Abu Sayyaf (ASG), Pejuang Pembebasan Islam Bangsa Moro (BIFF), dan Khalifah Ansar Filipina (KAP)/Ansuar al-Khalifa Filipina (AKP), ${ }^{52}$ yang kesemuanya telah menyatakan kesetiaannya pada ISIS. ${ }^{53}$ Mereka adalah kelompok yang tidak menyetujui jalan damai MILF dan MNLF dengan Pemerintah Filipina dengan pemberian otonomi, demi terbentuknya sebuah negara Islam di Filipina Selatan.

Sementara, Isnilon Totoni Hapilon, komandanKelompokAbuSayyaf, kemunculannya di dasawarsa 1990 dibantu oleh Al-Qaeda. Ia telah menyatakan kesetiaannya kepada ISIS/IS pada 2014, dan sejak itu ia telah membangun sebuah aliansi dengan keluarga Kelompok Maute, klan bangsawan pemilik tanah yang mengomandoi ratusan pengikut ekstrimnya. Kelompok Maute terorganisasi dengan baik dan memiliki akses pendanaan. Ominta "Farhana" Romato Maute, ibu dari pemimpin Maute, adalah pengusaha dan sekaligus politikus yang cerdik, yang memiliki banyak rumah dan mengelola beberapa bisnis, termasuk menyewakan bangunan di Quezon City dan kota-kota penting lainnya, seperti Iligan, Cotabato, dan Davao. ${ }^{54}$

\footnotetext{
Wawancara dengan Kol. Laut (Pelaut) A.M. Susanto. Wawancara dengan Sidney Jones.

"NIIS Bisa Menyerang Balik," Kompas, 10 Juli 2017, 8.

"Ancaman Teror di Filipina Selatan," Koran Tempo, 14 Juni 2017, 22.

54 "Parlemen Filipina Desak Aset Maute Dibekukan," Koran Tempo, 13 Juni 2017, 6.
}

Keterlibatan orang-orang Maute dalam bisnis narkoba memberikan mereka sumber dana baru yang potensial di samping dana operasional yang bersumber dari aksi-aksi pembajakan kapal, penculikan orang asing dan permintaan tebusan uang, yang selama ini diandalkan Kelompok Abu Sayyaf. ${ }^{55}$ Dalam operasinya menumpas Kelompok Maute di Kota Marawi, Militer Filipina telah menyita 11 kilogram narkotika jenis sabu, senilai 250 juta Peso atau Rp. 66 milyar, di samping 20 senjata api berkekuatan tinggi, yang berbeda dengan senjata api biasa. ${ }^{56}$ Temuan ini memperkuat indikasi telah terciptanya kegiatan narcoterrorism seperti yang telah diperkirakan Presiden Duterte, dengan kelompok teroris menggunakan bisnis narkoba untuk membiayai aktivitas terorisme mereka. Ini membenarkan pandangan Philip Divett, Analis Pencegahan Teroris dari Wina dan UNODC, yang telah mengungkapkan hubungan antara terorisme dengan kejahatan lintas-negara lainnya, yang berkembang di sebuah wilayah. ${ }^{57}$

Belajar dari sepak terjang kelompokkelompok separatis MNLF dan MILF sebelum ini, aksi terorisme untuk menguasai Kota Marawi akan dijadikan model bisnis para kelompok teroris pro-ISIS di Asia Tenggara untuk menyerang kekuatan-kekuatan pemerintah. Konsekuensinya akan mahal bagi negara-negara di dalam dan luar kawasan, sebab akan meningkatkan instabilitas, sektarianisme, serta mengganggu perkembangan dan pertumbuhan ekonomi dan menciptakan kian banyak citra negatif bagi prospek kawasan ini di masa depan. ${ }^{58}$ Sedangkan buat para teroris proISIS, sukses serangan mereka ini merupakan permainan zero-sum game yang positif, terkait upaya mereka merekrut lebih banyak pengikut, pendukung dan simpatisan mereka, serta

\footnotetext{
55 "Krisis Mindanao: Kehadiran Milisi Asing Bukti Ancaman NIIS," Kompas, 2 Juni 2017, 1 dan 15.

56 "Militer Sita Sabu Rp. 66 Miliar dari Marawi," Koran Tempo, 21 Juni 2017, 23.

57 Wawancara dengan Philip Divett, Terrorism Prevention Branch, UNODC, di Hotel Aryaduta DPR Jakarta pada 30 Maret 2017.

58 Jasminder Singh,"The 2017 Marawi attack: Implications for regional security," The Jakarta Post, 20 Juni 2017, 7.
} 
memperluas publisitas sumber daya dan teritori yang mereka kuasai. Nama tokoh ISIS di Filipina Selatan, Isnilon Totoni Hapilon, yang identik dengan nama lain sebagai Abu-Abdullah alFilibini dan Abu Abdillah al-Muhajir, seperti disebut-sebut dalam majalah ISIS, Rumiyah, ${ }^{59}$ mendeskripsikan ketokohan Hapilon yang bisa diterima tidak hanya di Filipina, tetapi juga di Malaysia dan Indonesia, atau Asia Tenggara dalam konteks yang lebih luas.

Kelompok militan pengikut ISIS/IS menjadikan wilayah Filipina Selatan, sebagai tempat pelarian dan perlindungan yang ideal, karena akses masuk banyak tersedia dari berbagai pulau di sekeliling perairan perbatasan ketiga negara. ${ }^{60}$ Selama ini juga tidak ada patroli laut, baik dari aparat Imigrasi, Polisi Air, Coast Guard maupun Angkatan Laut ketiga negara, yang efektif dapat mencegah keluar-masuknya kelompok radikal Muslim ke wilayah Filipina Selatan. ${ }^{61}$ Kemunduran di Suriah dan Irak telah membuka mata pimpinan ISIS/IS di pusat untuk membuka teater atau mandala perang baru di Asia Tenggara. ${ }^{62}$ Wilayah Filipina Selatan, yang selama ini dikuasai penduduk dan penguasa Muslim tampaknya telah menjadi pilihan ideal bagi mereka yang ingin melanjutkan perjuangan membangun Kekhalifahan Islam dari wilayah terdekat, tanpa harus melakukan jihad jauh ke Timur-Tengah, yang semakin sulit ditembus medannya akibat kontrol di setiap perbatasan negara yang kian ketat. Untuk menghadapi perkembangan yang buruk di ini, para pengikut dan pendukung ISIS/IS di Asia Tenggara telah diserukan untuk hijrah ke Filipina Selatan.

Sejalan dengan itu, pimpinan ISIS/IS di pusat, secara pro-aktif, selalu mengklaim aksi-

\footnotetext{
Ibid.

Wawancara dengan Kol. Laut (Pelaut) A.M. Susanto.

Wawancara dengan Kol. Laut (Pelaut) A.M. Susanto Juga, terungkap dalam wawancara dengan Letkol Maftukin, Danlanal Melonguane yang baru, dan dengan Mayor (inf) S.W. Panaha, perwira Kodim Santiago Melonguane, serta Serka Buntomo Sampe, Prajurit Posal Miangas, dan Mayor (inf) Sonny Saerang, Danramil Miangas pada 4-5 Juni 2017 di Kecamatan Pulau Miangas.

62 Sidney Jones, Direktur IPAC, Jakarta, dalam Richard C. Paddock, "Duterte ignored rise of ISIS," The New York Times International, June 13, 2017.
}

aksi terorisme yang telah dilakukan kelompok militan Muslim pengikutnya di kawasan ini sebagai aksi-aksi ISIS/IS. Memang, struktur organisasi ISIS di Asia Tenggara, yang baru direstui dibentuk oleh ISIS pusat, berbeda dengan JI (Jamaah Islamiyah), yang jelas pembentukan dan eksistensinya di kawasan yang sama. (Kekhalifahan) ISIS di Asia Tenggara ini tidak memiliki struktur organisasi yang jelas, juga terkait hubungan operasional mereka dengan pusat (Timur-Tengah, terutama Suriah dan Irak, asalnya organisasi lintas-negara ini dideklarasikan pembentukannya) secara langsung. ${ }^{63}$ Pendeklarasian diri secara terbuka mendukung ISIS di Suriah dan Irak atau proses baiat dilakukan secara sukarela oleh kelompokkelompok radikal di kawasan ini. Komunikasi dengan pemimpin ISIS di pusat terlacak ada oleh aparat keamanan Indonesia, seperti dengan Bachrumsyah dan Bachrum Naim, yang keduanya berasal dari Indonesia.

Secara realistis, tanpa harus menunggu ada struktur organisasi baru yang resmi terbentuk, para pengikut dalam kelompok-kelompok pro-ISIS dan secara perorangan (lone-wolf) di Asia Tenggara, yang baru mendeklarasikan dukungannya (membaiat diri) secara terbuka, telah banyak dan berhasil melakukan aksi-aksi atau serangan terorisme di lapangan. Lebih jauh lagi, biasanya, pasca-serangan terorisme mereka, para pengikut dan pendukung, ataupun simpatisan, ISIS di kawasan ini langsung memberikan pernyataan bahwa aksiaksi mereka dilakukan atas nama (kepentngan) ISIS. Sebaliknya, pemimpin ISIS di pusat, yaitu Suriah dan Irak, memberikan pernyataan secara terpisah atau sepihak bahwa serangan terorisme yang baru saja dilakukan kelompok-kelompok radikal pengikut, pendukung atau simpatisan mereka adalah aksi-aksi yang mereka restui.

Sederhananya, modus-operandi ISIS di Asia Tenggara ini seperti organisasi yang beroperasi dan bergerak tanpa tergantung pada struktur dan bentuk fisik. Jika ada pemimpin penting

\footnotetext{
63 Wawancara dengan Sidney Jones juga dalam penjelasan Sidney Jones atas pertanyaan tertulis, disampaikan pada 26 April 2017.
} 
yang tewas akibat penumpasan oleh operasi militer pemerintah, dengan cepat mereka bisa menggantinya dengan pemimpin baru, walaupun belum tentu tidak menimbulkan friksi, karena perbedaan kedekatan latar belakang etnik, asal dan pengalaman dan kebersamaan dalam perjuangan. Bagi pengamat sendiri, apalagi seperti Sidney Jones, yang sejak lama mengamati konflik-konflik sosial di kawasan, ISIS bukanlah gerakan radikal atau organisasi baru, yang juga mengaitkan perjuangannya dengan Islam. Itulah sebabnya, ia menyebut JI telah muncul sebagai ISIS di Asia Tenggara. Dengan kata lain, Jones menyebut ISIS sebagai organisasi jelmaan dan wajah baru dari JI, untuk melanjutkan idealisme perjuangan para pendiri, pemimpin dan pengikutnya di kawasan. ${ }^{64}$

Lebih jelas lagi, perlu diungkapkan, kecuali JI, kelompok-kelompok radikal seperti MNLF, MILF, Abu Sayyaf, dan BIFF, yang menyatakan diri sebagai pengikut/pendukung ISIS di Asia Tenggara itu, tidak serta merta sejak lahir telah menjadi, atau terlahir sebagai, organisasi ISIS di kawasan. Mereka sejak lama telah dikenal dan terlahir sebagai kelompok-kelompok separatisme di wilayah Filipina Selatan, yang mengkampanyekan dan memperjuangkan berdirinya negara sendiri, yang terpisah, dari Pemerintah Filipina, yang berpusat di ibukota Manila. Dalam perjalanan waktu, ketidakpuasan yang muncul pasca-pemberian dan pengakuan secara resmi otonomi di Filipina Selatan oleh Manila kepada pemimpin dan pejuang senior mereka seperti Nur Misuari dan kawan-kawan, telah membuat kelompok-kelompok separatis itu kemudian menyatakan secara sepihak sebagai pengikut ISIS, dengan membawa misi lebih jauh mendirikan 'kekhalifahan satelit' di Asia Tenggara. ${ }^{65}$

Kelompok Maute, yang sebelumnya dikenal sebagai Khilafah Islamiyah Mindanao (KIM), adalah sel ISIS/IS yang paling berbahaya

\footnotetext{
64 Wawancara dengan Sidney Jones juga dalam penjelasan Sidney Jones atas pertanyaan tertulis, disampaikan pada 26 April 2017.

65 Lihat kembali, "NIIS Bisa Menyerang Balik," Kompas, 10 Juli 2017, 8, Lihat juga kembali "Ancaman Teror di Filipina Selatan,” Koran Tempo, 14 Juni 2017, 22.
}

di Filipina, khususnya wilayah Mindanao, Filipina Selatan, yang dikontrolnya. Salah satu pendirinya, Omarkhayam Romato Maute, menikah dengan perempuan WNI, Minhati Madrais, teman studinya di Universitas Al-Azhar, Kairo, Mesir. Ia sempat mengajar di pesantren milik keluarga Madrais di Bekasi, Jawa Barat, sekembalinya dari Mesir tahun 2009. Bersama adiknya, Abdullah, mereka mempunyai mentor berasal dari Tegal, yakni, Sanusi. ${ }^{66}$ Milisi Maute ini adalah pendukung Isnilon Totoni Hapilon, yang kian santer disebut sebagai pemimpin ISIS di Asia Tenggara. Selain dibantu mitranya dari Malaysia, Dr. Ahmad Mahmud, Hapilon dan Maute bersaudara didukung dan dilindungi oleh Abdullah Macapagar, salah satu komandan MILF, dalam aksi-aksinya.

Hapilon awalnya dikenal sebagai pemimpin Kelompok Abu Sayyaf, yang sering melakukan pembajakan kapal dan penculikan warga asing, untuk mendapatkan tebusan demi mendukung aktivitas organisasinya. Sejak tahun 2014, aktivitasnya mendapat respons lebih hebat dari militer Filipina, setelah ia bertindak semakin kejam dengan aksi penggal kepala kepada sanderanya yang tidak mengirim uang tebusan, terutama setelah ia membaiat pada ISIS/IS pusat. ${ }^{67}$ Sejak itu, selain peran Hapilon secara simbolik sebagai tokoh teroris di kawasan kian penting, wilayah Filipina Selatan menjadi pusat perhatian kampanye militer Filipina, dan juga pemerintah di Asia Tenggara, mengingat semakin banyaknya tersebar kelompok teroris yang berbaiat pada ISIS/IS.

Secara realistis, dewasa ini, Kelompok Abu Sayyaf telah berkembang dari gerakan separatis menjadi pengusung jihad di Filipina Selatan. Di pertengahan dasawarsa 1990, kelompok ini semula berafiliasi secara longgar kepada Al-Qaeda. Aksi-aksi terorismenya beragam, dan terus berkembang, mulai dari penculikan, pembunuhan, pemboman kapal ferry di tahun 2004 dan bus di Manila tahun

\footnotetext{
66 "Sel NIIS Ada di 16 Daerah," Kompas, 16 Juni 2016, 1 dan 15 .

67 Jake Maxwell Watts,"Clashes Escalate in Southern Philippines," The Wall Street Journal," 25 Mei 2017, 1 \&A2.
} 
2005. Pemerintah Filipina dengan bantuan AS, pasca-Peristiwa 9 September 2001, berupaya mengeliminasi pemimpin Kelompok Abu Sayyaf, tetapi kemudian muncul pemimpin baru, hingga Hapilon sekarang ini, yang memiliki kemampuan membangun solidaritas dengan kelompok-kelompok militan Muslim lainnya di Filipina. Ia telah dianggap sebagai "Emir" kelompok militan Muslim di Filipina Selatan, dan dengan mengatasnamakan ISIS/ IS melalui serangan terorisme mereka ke Kota Marawi, Hapilon dan Kelompok Maute, yang baru bergabung, berupaya menaikkan pamor mereka. ${ }^{68}$

\section{FTFS DAN PENGIRIMAN DANA DAN SENJATA SEBAGAI INDIKATOR}

Kehadiran FTFs juga menjadi indikator kehadiran kekhalifahan ISIS di kawasan ini. Ketika serbuan kelompok teroris pro-ISIS/IS Maute ke Marawi, Pulau Mindanao, Filipina Selatan, berlangsung, terdapat 7 WNI, yang oleh Kepolisian Filipina diperkirakan terlibat jejaring dan aktivitas terorisme ISIS/IS di Kota Marawi. Dua dari mereka dengan identitas dari Jawa Barat. Adapun 4 orang telah masuk dalam Daftar Pencarian Orang (DPO) Kepolisian Nasional Filipina, karena telah jelas terungkap bergabung dalam milisi Maute, yang telah berafiliasi ke ISIS/IS. ${ }^{69}$ Keempat WNI itu diduga adalah anggota Jamaah Ansharut Daulah Khilafah Nusantara (JADKN), pengikut Aman (Oman) Abdurrahman. ${ }^{70}$ JADKN dibentuk pada Maret 2015 dengan anggotanya kelompok JI, Al-Muhajirun, MIT, MIB, yang berbaiat pada ISIS. Mayoritas yang bertempur di Marawi adalah pengikut JAD dari Pulau Jawa, seperti Jawa Barat, Jawa Tengah, dan Jawa Timur, Nusa Tenggara Barat dan Sulawesi Selatan. Para pengikut JAD inilah yang sebelumnya telah menjadi pelaku serangan teroris sejak Januari 2016 hingga Mei 2017 di Indonesia,

\footnotetext{
68 Watts,"Clashes Escalate in Southern Philippines".

69 "Krisis Mindanao: Kehadiran Milisi Asing Bukti Ancaman NIIS," Kompas, 2 Juni 2017.

70 Al-Chaidar dalam, "Patroli Batas Sulut-Filipina Makin Ketat," Manado Post, 2 Juni 2017, 1 \& 11 juga wawancara dengan Sidney Jones.
}

dengan sasaran utama aparat kepolisian, aparat dan simbol-simbol negara, perwakilan negara Barat, dan kelompok agama lain. ${ }^{71}$

Mereka masuk secara legal ke Filipina Selatan antara Nopember 2016 serta Maret dan April 2017. Kecuali 1 orang yang sudah tewas, keberadaan mereka tidak diketahui setelah dimulainya operasi militer yang diperintahkan Presiden Filipina, Duterte. Mereka memang tidak masuk dalam daftar anggota jaringan teroris yang tengah diburu aparat anti-teroris Indonesia (Densus 88), ${ }^{72}$ namun bukan berarti boleh lepas dari perhatian aparat keamanan di kedua negara. ${ }^{73}$ Perkembangan terakhir mengungkap keterlibatan lebih banyak WNI setelah Polri mengumumkan terdapat $38 \mathrm{WNI}$, terdiri dari 37 laki-laki dan 1 perempuan, terlibat aktivitas jejaring terorisme pro-ISIS/ IS di Kota Marawi, Filipina, yang sedang berperang dengan militer negeri itu. Sebanyak 4 orang dari mereka diduga telah tewas, 6 sudah kembali ke Indonesia, 6 lainnya dideportasi Pemerintah Filipina, dan 22 orang masih di Filipina. ${ }^{74} \mathrm{Ke}-38$ WNI itu masuk ke Filipina secara ilegal. Aktivitas ke-12 orang yang sudah kembali ke Indonesia itu tengah didalami dan terus dipantau. ${ }^{75}$

Bersama dengan aktivitas Kelompok Abu Sayyaf lainnya yang meningkat belakangan ini di Laut Sulu dengan aksi-aksi pembajakan kapal dan penyanderaan mereka, Kepulauan Sulu menjadi wilayah pilihan pembangunan pusat-pusat perlawanan baru ISIS/IS di Asia

\footnotetext{
71 "Kombatan Indonesia di Marawi Anggota JAD”, Koran Tempo, 8 Juni 2017, 1.

72 "Kombatan Indonesia di Marawi Anggota JAD".

73 Wawancara dengan Letkol Maftukin, Danlanal Melonguane, serta Mayor (inf) S.W. Panaha, Kodim Santiago Melonguane, dan Mayor (inf) Sonny Saerang, Danramil Miangas, pada 4 Juni di Miangas.; juga wawancara dengan Kenangan Lupa, Kepala Kantor Imigrasi Miangas, pada 7 Juni 2017 di Miangas.

74 "Konflik Marawi: 38 WNI Terlibat Terorisme di Filipina," Koran Jakarta, 3-4 Juni 2017, 1.

75 “Empat WNI Tewas di Marawi," Manado Post, 3 Juni 2017: 1 dan 11; juga terungkap dalam wawancara dengan Letkol Maftukin, Danlanal Melonguane, serta Mayor (inf) S.W. Panaha, Kodim Santiago Melonguane, dan Mayor (inf) Sonny Saerang, Danramil Miangas, pada 4 Juni di Miangas.
} 
Tenggara, ${ }^{76}$ sebagai implementasi kebijakan divergensi ISIS/IS di tingkat pusat. Dalam serangan ke Kota Marawi pada 23 Mei 2017 lalu, aparat keamanan Filipina telah mencatat keterlibatan milisi asing (FTFs), antara lain berkewarganegaraan Arab Saudi, Chechnya, Yaman, Malaysia, Indonesia, dan bahkan Singapura, ${ }^{77}$ yang ditemukan tewas. Keberadaan FTFs di Kota Marawi ini mengindikasikan telah dijadikannya wilayah negara Filipina sebagai basis operasi ISIS/IS, seperti telah diantisipasi Presiden Duterte.

Marawi, ibukota Provinsi Lanao del Sur, di Pulau Mindanao, adalah salah satu kota di Filipina Selatan, yang telah menjadi medan tempur para pengikut ISIS di Filipina dan FTFs lainnya dari berbagai kewarganegaraan, khususnya Timur-Tengah. Kalau kawasan ini berkembang menjadi sarang perlawanan dan basis kekuatan ISIS adalah logis, sebab, sejak tahun 1994 sampai tahun 2006, MILF telah menggunakan wilayah Filipina Selatan ini sebagai basis perjuangan bersenjatanya. Wilayah yang dibatasi perairan di sekelilingnya dengan negara-negara tertangga ASEAN lainnya, selama ini tidak terkontrol dengan baik oleh aparat keamanan dan pertahanan ketiga negara. Baru sekarang saja, setelah muncul dan meningkatnya ancaman ISIS, Pemerintah Filipina dan 2 negara tetangganya itu memberikan perhatian serius, dengan merancang dan menggelar operasi patroli militer bersama. ${ }^{78}$

Filipina Selatan telah menjadi kawasan yang disukai dan dipilih ISIS sebagai 'Kekhalifahan Asia Tenggara'-nya, karena posisi geografisnya yang ideal, untuk aksi-aksi terorisme dalam jangka panjang dengan strategi gerilya. Kesulitan

76 "Empat WNI Tewas di Marawi," Manado Post, 3 Juni 2017: 1 dan 11; juga terungkap dalam wawancara dengan Letkol Maftukin, Danlanal Melonguane, serta Mayor (inf) S.W. Panaha, Kodim Santiago Melonguane, dan Mayor (inf) Sonny Saerang, Danramil Miangas, pada 4 Juni di Miangas.

77 Lihat, "MA Filipina Dukung Duterte," Kompas, 5 Juli 2017, 10.

78 Wawancara dengan Letkol Maftukin, Danlanal Melonguane, serta Mayor (inf) S.W. Panaha, Kodim Santiago Melonguane, dan Mayor (inf) Sonny Saerang, Danramil Miangas, pada 4 Juni di Miangas. pemerintah ketiga negara mengontrol wilayah ini, yang memang jauh dari pusat pemerintahan masing-masing negara (Manila-Kuala LumpurJakarta), dan akses yang luas untuk keluar masuk, apalagi ke dan dari perairan Indonesia, membuat wilayah Filipina Selatan sangat ideal untuk basis aktivitas 'terorisme perairan' dan kekhalifahan ISIS di kawasan. ${ }^{79}$ Selama ini, basis aktivitas 'terorisme daratan' di Suriah dan Irak, juga Libya, mudah dikepung dan diserang bersama-sama oleh pasukan koalisi pro-AS atau Rusia, untuk dihancurkan.

Bebasnya senjata api masuk dari luar dan dalam wilayah perairan memberi nilai tambah kawasan ini untuk dijadikan basis militer dan perlawanan. ${ }^{80}$ Kondisi domestik Filipina yang rapuh dengan berbagai praktek KKN (Kolusi, Korupsi, dan Nepotisme), dalam sebuah sistem yang diwarnai feodalisme, penyalahgunaan kekuasaan, dan kesenjangan ekonomi sejak lama, dan belum berubah, telah memungkinkan senjata-senjata mudah didapat, termasuk dari kalangan militer Filipina sendiri. ${ }^{81}$ Itulah sebabnya, selama 4 pekan, Kelompok Maute dan Abu Sayyaf yang pro-ISIS di Marawi, yang sebelumnya kurang diperhitungkan kekuatannya oleh pengamat di kawasan, menjadi sulit dihentikan perlawanannya. Tenggat waktu operasi militer Presiden Duterte untuk membebaskan Kota Marawi pada 12 Juni 2017 kini sudah terlampaui. Berkepanjangannya operasi militer di Marawi, dan kehadiran militer AS sebagai penasehat tempur dan pemberian bantuan perlengkapan militer, ${ }^{82}$ yang sebelumnya

\footnotetext{
Wawancara dengan Kol. Laut (Pelaut) A.M. Susanto, SW. Wawancara dengan Kol. Laut (Pelaut) A.M. Susanto, SW juga wawancara dengan Denny Sondakh, Kabag Hukum Pemerintah Kabupaten Kepulauan Talaud, pada 13 Mei 2016 di Melonguane.

81 Ali Fauzi dan Nasi Abbas, mantan pengikut JI yang pernah ikut pelatihan dan berperang bersama Kelompok MILF/ Abu Sayyaf, lihat,"Penilaian Eks WNI Milisi Mindanao: ISIS Tidak Akan Bisa Bercokol di Indonesia," Rakyat Merdeka, 17 Juni 2017: 10.

82 Terdapat 300-500 personil militer AS di Filipina, yang 50100 dari mereka adalah pasukan khusus yang memberian pelatihan dan nasehat serta menjalankan misi-misi bantuan, dengan fokusnya pada counter-terrorism, di bawah program Joint United Sattes Military Assistance Group, lihat,"Jake Maxwell Watts," U.S. Forces Back Philippine
} 
tidak dikehendaki, selain telah menunjukkan terbatasnya kemampuan Militer Filipina dalam merespons para kelompok teroris domestik proISIS yang telah dibantu FTFs, juga semakin menunjukkan keinginan ISIS yang kuat dalam membangun 'Kekhalifahan Asia Tenggara-nya'.

Kehadiran FTFs dari berbagai negara, tidak hanya Indonesia, Malaysia, Singapura, ${ }^{83}$ dan negara ASEAN lainnya, namun juga TimurTengah, seperti Arab Saudi, Yaman, Mesir, dan negara-negara lainnya, termasuk India dan Chechnya, telah menjadikan pertempuran semakin kompleks dan menyulitkan militer Filipina, sehingga Presiden Duterte harus mengerahkan helikopter dan menggunakan serangan udara. Keterlibatan FTFs kian memperkuat indikasi dijadikannya kawasan Filipina Selatan yang tidak terkontrol oleh militer Filipina ini sebagai basis 'Kekhalifahan ISIS/IS di Asia Tenggara'. Kehadiran mereka tidak lagi sekadar membantu demi semangat persaudaraan sejagad, tetapi sebagai upaya serius menjadikan Filipina Selatan sebagai basis baru perjuangan dan perlawanan ISIS/IS. ${ }^{84}$

Kawasan Filipina Selatan menyediakan pusat konflik baru yang dapat menjadi batu pijakan bagi ISIS/IS untuk menyebarkan ideologi dan mengembangkan pengaruh globalnya. ${ }^{85}$ Upaya ISIS/IS menjadikan Filipina Selatan, terutama Mindanao, sebagai basis kekhalifahan baru, dengan memanfaatkan eksistensi dan peran para pengikutnya, pendukung dan simpatisannya di sekitar wilayah ini, bukan rahasia yang dapat

Fight," The Wall Street Journal, June 12, 2017: A3. Senjata yang disuplai militer AS untuk memerangi kelompokkelompok teroris di Marawi mencakup 300 karabin M4, 200 pistol Glock 21, 4 senapan mesin M134D, dan 100 pelontar granat M203. Lihat, Sukma Loppies,"AS Pasok Senjata ke Filipina," Koran Tempo, 6 Juni 2017: 23.

83 Warga Singapura di antaranya adalah Muhamad Ali Abdul Rahman atau Muawiya, yang telah beroperasi di Filipina Selatan sejak tahun 1990-an. Ia telah ditemukan tewas bersama militan dari berbagai negara lainnya. Lihat, Natalia Santi,"Militer Filipina Temukan Jasad Milisi Asal Indonesia," Koran Tempo, 5 Juli 2017: 26.

84 "Krisis Mindanao: Militer Filipina Gencarkan Serangan," Kompas, 18 Juni 2017: $1 \& 15$.

85 Richard C. Paddock. "Duterte ignored rise of ISIS," The New York Times International, 13 Juni 2017, 6. disimpan oleh organisasi itu, karena semakin tersibak dari yang berkembang di lapangan. ${ }^{86}$ Penggunaan senjata-senjata canggih, yang dilengkapi drone, dan amunisi yang tidak terbatas, karena dukungan luar, termasuk pendanaan lintas-batas, menimbulkan kecemasan mendalam dari para pemimpin di kawasan terhadap akan berkembangnya wilayah ini sebagai pusat perlawanan ISIS/IS di Asia Tenggara. ${ }^{87}$

Sebelum ini, juga telah terdeteksi aliran dana sebesar US\$ 55.000 dari ISIS/IS Suriah dan Irak, yang dikirimkan oleh Bahrumsyah alias Bahrum Naim, pemimpin Katibah Nusantara, cikal-bakal kelompok perlawanan ISIS/IS di kawasan. Dana dikirim melalui Achmad Supriyanto alias Damar, anggota JAD di Banten, yang kemudian mengirimkannya ke Filipina dengan menggunakan jasa Western Union. Pengiriman dana ini kemudian terdeteksi oleh PPATK di Indonesia. ${ }^{88} \mathrm{Di}$ samping itu, ada pengiriman dana sebesar US\$ 600.000 dari ISIS/IS di Timur-Tengah ke Dr. Mahmud Ahmad, mantan dosen di Malaysia, pengikut ISIS di Malaysia, yang duduk dalam lingkaran struktur komando aksi di Marawi. ${ }^{89}$ Semua dana ISIS/IS pusat ini dikirimkan untuk kepentingan penyebaran misinya di Asia Tenggara, sehingga telah mendorong para pemimpin di kawasan menyiapkan langkah serius bersama-sama untuk meresponsnya, lewat pertemuan Manado. Adapun Bahrum Naim dan Abu Walid, rekannya, di Katibah

86 Lihat, "A Caliphate Grows in the Philippines," The Wall Street Journal, June 14, 2017: A10; Wawancara dengan Kol. Laut (Pelaut) A.M. Susanto, SW Juga dalam wawancara dengan Kol. Laut (Pelaut) Ivong Wibowo, Asisten Intelijen Lantamal VII.

87 Lihat, "A Caliphate Grows in the Philippines," The Wall Street Journal, June 14, 2017: A10; Wawancara dengan Kol. Laut (Pelaut) A.M. Susanto, SW Juga dalam wawancara dengan Kol. Laut (Pelaut) Ivong Wibowo, Asisten Intelijen Lantamal VII juga wawancara dengan Kol. Laut (Pelaut) I. Putu Daryatna, Asisten Perencanaan Lantamal VIII, pada 11 Mei 2016 di Manado.

88 Lihat Laporan IPAC dan juga PPATK, dalam "Indonesia Undang 5 Negara Bahas Konflik di Marawi," Media Indonesia, 27 Juli 2017, 4.

89 Marguerite Afra Sapiie and Haeril Halim,"Report warns of Marawi battle fallout, The Jakarta Post, 22 Juli 2017, 2. 
Nusantara, memiliki ikatan yang kuat dengan rekan-rekan mereka di Mindanao. ${ }^{90}$

\section{RESPONS GLOBAL INDIKATOR \\ SEBAGAI}

Akibat perannya yang kian membahayakan, Departemen Kehakiman AS, telah mengumumkan Hapilon sebagai "teroris yang sangat dicari" di dunia dewasa ini, dengan harga kepalanya US\$ 5 juta. ${ }^{91}$ AS menilai Hapilon bertanggungjawab atas penculikan di tahun 2001, dengan menyandera 20 orang, seorang di antaranya warga AS, yang kemudian dipenggal setelah diculik dari sebuah resort. Ketidakmampuan Pemerintah Filipina mengeliminasi Kelompok Hapilon, Maute dan lain-lain telah mengundang kekuatiran negara tetangganya, termasuk Australia. Karena itulah, pada Februari 2017, Menlu Julie Bishop telah mengungkapkan kesiapan negaranya untuk merespons pendeklarasian Kekhalifahan ISIS/IS di Filipina Selatan." Walaupun kelompok-kelompok teroris di Filipina semula berlatarbelakang etnik dan ideologi yang beragam, munculnya seorang pemimpin yang bisa membangun solidaritas, seperti Hapilon, melalui aksi-aksi terorisme yang bisa memberi inspirasi, bukan tidak mungkin dapat menyatukan mereka dalam sebuah 'Kekhalifahan ISIS/IS di Asia Tenggara,' yang mereka harapkan dan berupaya bangun.

Walaupun militer Filipina berhasil menangkap saudara Omarkhayam dan Abdullah, yaitu Mohammad Noaim Maute, pemimpin negara di kawasan kian menyadari berbahayanya pengaruh ISIS/IS di kawasan. Karenanya, para Menhan 5 dari Indonesia, Malaysia, Filipina, Singapura, dan Brunei telah memutuskan bertemu di Tarakan, Kalimantan Utara, pada 19 Juni 2017 untuk membahas strategi menangani pengaruh ISIS/IS. ${ }^{92}$

\footnotetext{
90 Wawancara dengan Sidney Jones, analis keamanan dan terorisme internasional, Direktur The Institute for Policy and Analysis of Conflict (IPAC) pada 4 April 2016; juga dalam penjelasan Sidney Jones atas pertanyaan tertulis, disampaikan pada 26 April 2017.

Ibid.

92 "Sel NIIS Ada di 16 Daerah," Kompas, 16 Juni 2017, 1 dan 15.
}

Pertemuan ini menandai peluncuran patroli bersama militer "Indomalphi Quick Response", antara Angkatan Laut Indonesia, Malaysia dan Filipina, untuk mengamankan perbatasan perairan ketiga negara itu dari ancaman terorisme. Indonesia sendiri juga membangun sebuah Maritime Command Center (MCC) di Tarakan, yang letaknya berdekatan dan meniru MCC milik Malaysia yang sudah ada di Tawau dan MCC Filipina di Bongao. ${ }^{93}$ Fungsinya untuk pengendalian dari darat untuk operasi militer dan sekaligus koordinasi ketiga negara dalam penanggulangan ancaman dan serangan terorisme. ${ }^{94}$

Adapun Trilateral Maritime Patrol Indomalphi diluncurkan di Tarakan, Kalimantan Utara, pada 20 Juni 2017, dengan kehadiran Menhan Ryacudu dari Indonesia, serta mitranya Menhan Malaysia Dato' Seri Hishammuddin Tun Hussein dan Menhan Filipina Delvin N. Lorenzana, dari atas KRI dr Suharso 990.95 Adapun kehadiran Menteri Senior Singapaura, Dr. Maliki bin Osman, yang mewakili Menhan Singapura, dan Wamenhan Brunei, Dato Sri Abdul Aziz bin Haji Muhamad Tamit sebagai pemantau menandakan kegiatan tersebut berada dalam semangat dan sentralitas ASEAN. ${ }^{96}$ Tujuan kegiatan itu untuk menjaga stabilitas keamanan dan perdamaian di kawasan, yang tentu saja sejalan dengan implementasi penguatan pilar pertama ASEAN, yakni Pilar Politik dan Keamanan ASEAN.

Berselang 2 hari, yakni pada 22 Juni 2017, pertemuan ketiga Menhan Indonesia, Malaysia

93 Wawancara dengan Kapten Ali S.W, Bagian Intelijen Lantamal XIII Tarakan dan AKP Joko, Bagian Intelkam, Polres Tarakan Provinsi Kalimantan Utara, pada 2 Agustus 2017 di Tarakan; juga wawancara dengan Letkol (L) Pelaut Ari Aryono, Danlanal Nunukan pada 3 Agustus 2017 di Mako Lanal Nunukan.

94 "TNI Bangun Pusat Komando," Republika, 21 Juni 2017, 2.

95 Fira Nursyabani,"Tiga Negara Bahas Marawi," Republika, 21 Juni 2017, 4.

96 Wawancara dengan Kapten Ali S.W, Bagian Intelijen Lantamal XIII Tarakan dan AKP Joko, Bagian Intelkam, Polres Tarakan Provinsi Kalimantan Utara, pada 2 Agustus 2017 di Tarakan; juga wawancara dengan Letkol (L) Pelaut Ari Aryono, Danlanal Nunukan pada 3 Agustus 2017 di Mako Lanal Nunukan. 
dan Filipina ASEAN ini ditindaklanjuti dengan pertemuan ketiga Menlu mereka di Manila, Filipina. Di sana hadir pula Kepala Polisi Nasional, Badan Anti-Terorisme, dan Panglima Angkatan Bersenjata masing-masing negara, untuk membahas lebih lanjut prospek stabilitas keamanan subkawasan pasca-serangan terorisme pro-ISIS di Marawi, Filipina Selatan. Rangkaian pertemuan ini sesungguhnya merupakan kelanjutan dari pertemuan trilateral negara yang sama pada 5 Mei tahun 2016, yang telah diinisiasi oleh Presiden Joko Widodo di Yogyakarta. Waktu itu tujuannya masih terbatas untuk merespons aksi-aksi pembajakan kapal, penculikan dan penyanderaan ABK dan warga asing dan ASEAN oleh Kelompok Abu Sayyaf.

Para pemimpin ketiga negara itu mulai prihatin dengan aktivitas kelompok-kelompok teroris pro-ISIS di kawasan Asia Tenggara, yang semakin ekspansif dan agresif, sebab sekarang telah muncul terorisme dan pendudukan kelompok-kelompok pro-ISIS dengan para pengikutnya yang berlatarbelakang aneka kewarganegaraan. Kesepakatan tidak hanya dicapai untuk memerangi aksi-aksi para teroris di lapangan, tetapi juga di media sosial, untuk menangkal dan menghentikan maraknya radikalisme yang telah menjadi pemicu para teroris baru dalam melakukan aksi-aksi mereka, termasuk di Malaysia dan Singapura, yang selama ini belum memperoleh perhatian serius. ${ }^{97}$ Serangan kelompok-kelompok teroris pro-ISIS yang semakin gencar, tidak hanya ke Kota Marawi, tetapi juga ke sebuah desa di dekat kota Pigcawayan, pusat Pulau Mindanao, Filipina Selatan, pada 21 Juni 2017 oleh BIFF, ${ }^{98}$ telah membunyikan alarm kewaspadaan para pemimpin di kawasan, khususnya tetangga Filipina di perairan, yaitu Indonesia dan Malaysia, terhadap indikasi yang semakin kuat

97 Wawancara dengan Kapten Ali S.W, Bagian Intelijen Lantamal XIII Tarakan dan AKP Joko, Bagian Intelkam, Polres Tarakan Provinsi Kalimantan Utara, pada 2 Agustus 2017 di Tarakan; juga wawancara dengan Letkol (L) Pelaut Ari Aryono, Danlanal Nunukan pada 3 Agustus 2017 di Mako Lanal Nunukan.

98 Lihat, Ben Otto, "Philippines Islamist Attack Second Town," The Wall Street Journal, June 22, 2017: A5. mengenai pembetukan 'Kekhalifahan ISIS di Asia Tenggara. ${ }^{99}$

Demikian juga, dengan kesediaan Pemerintah China dan Australia untuk membantu operasi anti-terorisme melawan ISIS di kawasan, dengan pengerahan pesawatpesawat pengintai untuk sharing informasi intelijen dan operasi intai-tempur di lapangan. AS dan China sangat berkepentingan langsung untuk menjaga kawasan Asia Tenggara yang stabil demi menjaga kepentingannya, tidak hanya di Laut China Selatan, terutama demi menjaga keamanan kapal-kapal logistik mereka untuk menjamin kebutuhan suplai energi nasional mereka. Sedangkan Australia, yang selama ini belum meninggalkan perannya sebagai "sherif AS" di kawasan, berkepentingan dengan upaya pre-emptive-nya untuk mencegah ancaman yang bersifat limpahan konflik, yang dapat mengganggu kepentingan dan stabilitas keamanan negaranya. ASEAN dan negara-negara besar di luar kawasan sangat kuatir aksi pendudukan dan terorisme oleh kelompok-kelompok pro-ISIS yang meluas dan berkepanjangan di Filipina Selatan, jika dibiarkan, akan menjadi magnet besar, yang menarik lebih banyak lagi FTFs yang hijrah dari Timur-Tengah dan negara-negara lainnya untuk bertempur dan melanjutkan perjuangan ISIS dan menciptakan destabilisasi keamanan dan politik lebih luas di Asia Tenggara. ${ }^{100}$

Serangan teroris pro-ISIS/IS di Kota Marawi telah memberi wake-up call bagi negara besar --pemain tradisional-- di kawasan, untuk dapat merespons secara efektif ancaman mereka. Itulah sebabnya, pada 29-30 Juli 2017 di Manado, ibukota Provinsi Sulawesi Utara, induknya Kabupaten Miangas, wilayah perbatasan terdepan Indonesia-Filipina, telah diadakan pertemuan darurat Malaysia, Brunei Darussalam, Indonesia, Filipina, Australia, dan Selandia Baru. Pertemuan yang dikemas dengan

\footnotetext{
Tama Salim, "Indonesia calls trilateral meeting on counterterrorism," The Jakarta Post, June 21, 2017: 12.

100 Kepala Staf Angkatan Bersenjata Filipina, Jend. Eduardo Ano, dalam Raul Dancel, "Terrorism in Southeast Asia: 3 ASEAN countries to work on action plan," The Straits Times, 23 Juni 2017, A6.
} 
nama Subregional Meeting on Foreign Terrorist Fighters and Cross-Border Terrorism (SRM FTFCBT) ini bertujuan menyiapkan kebijakan counter-terorrism terhadap para teroris pengikut ISIS/IS di kawasan dan langkah franchising gerakan dan aksi-aksi terorisme ISIS/IS pusat di Timur-Tengah ke Asia Tenggara. ${ }^{101}$

Dapat dikatakan, pertemuan ini merupakan kelanjutan dari pertemuan Bali pada 9 Agustus 2016, mengenai pendanaan terorisme dan kontraterorisme, yang diselenggarakan bersama oleh Indonesia dan Australia. ${ }^{102}$ Berbeda dengan Pertemuan Bali, Pertemuan Manado dihadiri oleh petinggi negara yang lebih beragam, seperti Menhan Wiranto, Jaksa Agung Australia, George Brandis, Menlu Selandia Baru, Gerry Brownlee, Penasehat Keamanan Nasional Filipina, Hermogenes C. Esperon, Jr, Wakil Menteri Dalam Negeri Malaysia, Dato' Mashir Anak Kujat, Wakil Menteri Keamanan dan Media Brunei Darussalam, Dato Sri Paduka Hamdan bin Abu Bakar, dan Kepala BNPT, Komjen Suhardi Alius. Hal ini turut menggambarkan urgensi pertemuan dan kepentingan yang lebih luas dari negara-negara di kawasan atas ancaman lebih serius ISIS yang mulai disebarkan dari Kota Marawi, Filipina Selatan.

Kebijakan sub-regional beberapa negara anggota ASEAN tersebut disiapkan untuk memerangi FTFs di kawasan dengan strategi lintas-perbatasan mereka dan mencegah lebih jauh upaya subregionalisasi terorisme ISIS/ IS melalui kerjasama yang lebih erat dalam pencegahan terhadap pembiayaan aksiaksi terorisme ISIS/IS, dan seterusnya. Para pemimpin negara di kawasan Asia Tenggara, tidak hanya ASEAN, memiliki kekuatiran yang sama terhadap meningkatnya ancaman terorisme ISIS/IS, sehingga memerlukan pertemuan koordinasi langsung di Manado.

Indra Budiari, "6 countries to discuss terrorism," The Jakarta Post, 22 Juli 2017, 2.

102 Wawancara dengan AKP Joko, Bagian Intelkam, Polres Tarakan Provinsi Kalimantan Utara, pada 2 Agustus 2017 di Tarakan; juga wawancara dengan Letkol (L) Pelaut Ari Aryono, Danlanal Nunukan pada 3 Agustus 2017 di Mako Lanal Nunukan.

\section{PENUTUP}

Perkembangan aktivitas para pengikut ISIS di Asia Tenggara mengungkap telah eksisnya 'Kekhalifahan ISIS di kawasan,' walaupun belum memiliki bangun dan struktur organisasi yang jelas, apalagi kuat. Tetapi, terlepas dari ini, data lebih jauh telah mengungkap, secara realistis, aksi-aksi terorisme yang mereka lakukan telah teroganisasi dan memperoleh dukungan dari para pengikut, pendukung dan simpatisan beragam asal negara-negara dari dalam dan luar kawasan. Dalam hubungannya dengan diskusi teoritik, eksistensi ISIS di Asia Tenggara kian menguatkan perspektif ekonomi-politik dalam hubungan internasional dan pendekatan pluralismenya, khususnya mengenai kaitan derasnya arus globalisasi dan meluasnya marjinalisasi sebagai implikasinya. Sementara, para aktor non-negara bangkit sebagai penentang tata dunia baru itu untuk memperlihatkan resistensinya. Kondisi ini menunjukkan, tidak lagi pemerintah negara periferi bereaksi terhadap ketergantungan pada sistem dunia atau dominasi kapitalisme global, tetapi para aktor non-negara lintas-negara yang mengusung dan memperjuangkan tata dunia alternatif, dengan pembentukan khilafah sejagad. Sedangkan lawan para pengikut ISIS di kawasan ini adalah pemerintah nasional yang bekerja sama di tingkat regional dan global untuk mengatasi pertumbuhan dan perlawanan ISIS lebih luas.

Dinamika keamanan dan perkembangan yang cepat yang terjadi, dengan meningkatnya aksi-aksi terorisme ISIS/IS di kawasan dan berkepanjangannya pertempuran di Kota Marawi, dalam kenyataannya, telah membuat ahli konflik dan terorisme internasional di Asia Tenggara, yakni Sidney Jones, merubah secara drastis analisisnya. Ia kini begitu yakin para pengikut ISIS/IS global dan di tingkat lokal akan menjadikan Asia Tenggara sebagai basis aktivitas dan perlawanan baru ISIS/IS, sehingga memberikan ancaman dan peringatan yang serius bagi negara-negara di kawasan ini. Karena, Mindano, Filipina Selatan dan kawasan sekitarnya secara lebih luas menyediakan 
kawasan ini menjadi tuan rumah bagi sejumlah sel-sel kecil terorisme yang sudah ada, dan tumbuh selama ini, dengan kapasitas kekerasan dan indoktrinasi ideologi radikal mereka. Sedangkan Indonesia dan Malaysia, 2 negara dengan mayoritas Muslim di kawasan ini, dengan kehadiran banyak kota dan warganya yang kian radikal dan mendukung ISIS, menjadi negara yang paling rentan menghadapi ancaman dan serangan seperti di Filipina, terutama Kota Marawi. ${ }^{103}$

Perkembangan lingkungan strategis di lapangan ini pulalah yang oleh Jones diperkirakan dapat kembali menyatukan kedua faksi teroris di Indonesia, dan juga Malaysia, yang selama ini terbelah sikapnya, untuk melancarkan serangan yang sama di masa depan, jika aksi terorisme pro-ISIS/IS di Kota Marawi dapat diakhiri Pemerintah Filipina. Karena itulah, pakar konflik dan teroris internasional itu mengingatkan, sekalipun serangan terorisme di Kota Marawi dapat diakhiri Pemerintah Filipina, tetapi itu bukan akhir dari ancaman serangan terorisme (kelompok-kelompok pro-) ISIS/IS di kawasan. ${ }^{104}$ Kesimpulannya, 'Kekhalifahan ISIS di Asia Tenggara' sedang dibangun dan dikembangkan, dan bukan lagi cuma wacana.

\section{DAFTAR PUSTAKA}

\section{Buku}

Acharya, Amitav. The Making of Southeast Asia: International Relations of a Region. Singapore: ISEAS, 2012.

Agus SB. Merintis Jalan Mencegah Terorisme. Jakarta: Semarak Lautan Warna, 2014.

Alexander, Yonah and Dean Alexander, The Islamic State: Combating The Caliphate Without Borders. London: Lexington Books, 2015.

\footnotetext{
103 "Konflik Marawi: Asia Tenggara Hadapi Ancaman Baru," Suara Pembaruan, 22-23 Juli 2017, 14.

104 Ibid.
}

Ali, As'ád Said. Al-Qaeda: Tinjauan SosialPolitik, Ideologi dan Sepak Terjangnya. Jakarta: LP3ES, 2014.

Assad, Muhammad Haidar ISIS: Organisasi Teroris Paling Mengerikan Abad Ini. Jakarta: Zahira, 2014.

Berman, Eli Radical, Religious, and Violent: The New Economics of Terrorism, Massachussets, MIT Press, 2011.

Booth, Ken, "Security within Global Transformation," in Ken Booth (Ed.), Statecraft and Security: The Cold War and Beyond, Cambridge: Cambridge University Press, 1998.

Buzan, Barry. People, States $\mathcal{E}$ Fear: An Agenda for International Security Studies in the PostCold War Era, 1991, The University of Michigan, Harvester Wheatsheaf, 1991.

Djelantik, Sukawarsini Terorisme: Tinjauan Psiko-Politis, Peran Media, Kemiskinan, dan Keamanan Nasional. Jakarta: Pustaka Obor, 2010.

Golose, Petrus Reinhard. Deradikalisasi Terorisme. Jakarta: YPKIK, 2009.

Gray, John False Dawn: The Delusions of Global Capitalism, Granta, 1998.

Harvey, Robert Global Disorder, New York: Carroll \& Graf Publishers, 2003.

Heijmans., Annelies, Nicola Simmonds, and Hans van de Veen Searching for Peace in Asia Pacific: An Overview of Conflict Prevention and Peacebuilding Activities. London, Boulder: Lynne Rienner Publihsers, 2014.

Huntington, Samuel P. The Third Wave: Democratization in the Late Twentieth Century, Oklahoma: University of Oklahoma Press, Jan 1, 1993.

Jemadu, Aleksius Politik Global dalam Teori dan Praktek, Edisi 2, Yogyakarta: Graha Ilmu, 2014.

Jones, David Martin Globalisation and the New Terror: The Asia Pacific Dimension, Cheltenham: Edward Elgar, 2004. 
Kahfi, Syahdatul.Terorisme di Tengah Arus Global Demokrasi. Spectrum, 2006.

Kleinen, John and Manon Osseweijer Pirates, Ports, and Coasts in Asia: Historical and Contemporary Perspectives. Singapore: ISEAS, 2010.

Lister, Charles R The Syrian Jihad. Oxford: Oxford University Press, 2015.

Mabon, Simon Saudi Arabia and Iran: Power and Rivalry in the Middle East. London and New York: IB Tauris, 2016.

Neumann, Peter R Options and Strategies for Countering Online Radicalization in the United States. London: King's College, 2013.

Nicholson, Michael. International Relations, London: Macmillan Press Ltd, 1998.

Simonsen, Clifford E. and Jeremy R. Spindlove Terrorism Today: The Past, the Players, the Future. New Jersey: Prentice-Hall, 2004.

Singh, Daljit Terrorism in South and Southeast Asia in the Coming Decade. Singapore: ISEAS 2009.

Snowden, Lynne L.and Bradley C. Whitsel Terrorism: Research, Readings, and Realities. New Jersey: Prentice Hall, 2005.

Stern, Jessica Terror in the Name of God: Why Religious Militant Kills. New York. Harper Collins, 2003.

Stern, Jessica and J.M. Berger ISIS: The State of Terror. Ecco; Wiliam and Collins, 2015.

Thayer, Carlyle A "Southeast Asia's Regional Autonomy under Stress, Southeast Asian Affairs". Singapore: ISEAS, 2016.

Viotti, Paul R. and Mark V. Kauppi, International Relations Theory: Realism, Pluralism, Globalism, Second Edition, Boston, Massachusetts: Allyn and Bacon 1993.

Wahid, Abdul, Sunardi, dan Muhammad Imam Sidik Kejahatan Terorisme: Perspektif Agama, HAM, dan Hukum.Bandung: Refika Aditama, 2004.
Watts, Jake Maxwell." U.S. Forces Back Philippine Fight," The Wall Street Journal, June 12, 2017.

Whitetaker, David J Terrorist and Terrorism in the Contemporary World. London: Routledge, 2004.

White, Jonathan R Terrorism and Homeland Security. USA: Wadsworth, 2012.

\section{Jurnal}

Jones, David Martin; Smith, M L R "Organization vs. Ideology: The Lessons from Southeast Asia." Current Trends in Islamist Ideology, Vol. 12. Washington DC: Hudson Institute (2012): 92-123.

Kim, Hyung Jong and Lee, Poh Ping "The Changing Role of Dialogue in the International Relations of Southeast Asia."Asian Survey (Sept/Oct 2011): 515. Berkeley.(Sep/Oct 2011): 953-970.

Li, Wei "Near ISIS Threat-Islamic State of Irap and al-Sham seeks to extend its presence to Central Asia and beyond," Beijing Review, Beijing (2015).

Ramakrishna S, Kumar "The Growth of ISIS Extremism in Southeast Asia: Its Ideological and Cognitive Features - and Possible Policy Responses," New England Journal of Public Policy, Volume 29, Issue 1, Article 6, Singapore: Nanyang Technological University, 2017.

"Reflections of a Reformed Jihadist: The Story of Wan Min Wan Mat." Contemporary Southeast Asia, 38.3. Singapore (2016): 495-522.

Scholte, Jan Aart Scholte "Global Capitalism and the State," International Affairs, Vol. 73, No. 3 (1997): 427-452.

Thayer., Carlyle A “Southeast Asia's Regional Autonomy under Stress. Southeast Asian Affairs." Singapore: ISEAS (2016).: 3-18.

\section{Makalah/Laporan}

"Melemahkan Jaringan Kelompok Mujahidin di Indonesia: Pelajaran dari Maluku dan Poso". Policy Report. Jakarta: ICG, 2005. 
"Perpecahan antara Warga Indonesia Pendukung ISIS dan Resiko Meningkatnya Kekerasan", Laporan IPAC No.25, Jakarta, IPAC, 1 Februari 2016.

"Saudi Arabia Exporting Salafi Education and Radicalizing Indonesia's Muslims," GIGA Focus, No. 7, 2014: 1-8.

\section{Majalah}

"Jejaring ISIS di Kampung Melayu," Majalah Tempo, 29 Mei-4 Juni 2017.

"Amaliyah di Jalan yang Salah," Majalah Tempo, 25 Desember 2016.

Hincks, Joseph, "A Deadly New Front for ISIS," Time, 3 July 2017.

"Jaringan ISIS Tanah Jawa," Majalah Gatra, 26 Maret-1 April 2015.

"Jalur Rekrutmen Anggota ISIS," Majalah Tempo, 30 Maret-5 April 2015.

"Miskin di Kota dan di Desa," Majalah Tempo, 7-13 Maret 2106.

"Nahas Abu Wardah di Tambarana," Majalah Tempo, 25-31 Juli 2016.

"Public Enemy No. 1," Majalah Tempo, 25-31 Januari 2016.

"Sang Khalifah dan Bendera Hitamnya," Majalah Tempo, 1-7 Februari 2016.

"Sudah Jelas Terkait ISIS," Majalah Gatra, 28 Januari- 3 Februari 2016.

"The Face of Terror: Gunmen in Jakarta Rampage," Majalah Tempo, 18-24 Januari 2016.

Von Drehle, David. "The ISIS Trap," Time, Maret 2015.

“4,026 Kg Sabu Sepanjang Maret 2016,” Instara, April 2016/II.

\section{Suratkabar}

"A Caliphate Grows in the Philippines," The Wall Street Journal, 14 Juni 2017.

Adolong, Sriwani dan Grand Regar,"Wilayah Pesisir Rawan Disusupi Teroris," Manado Post, 3 Juni 2017.
"Amankan Perbatasan Laut, Lanal Tambah Armada," Radar Nunukan, 1 Agustus 2017.

"Ancaman Teror di Filipina Selatan," Koran Tempo, 14 Juni 2017.

Aruperes, Eva."City close to Philippines wary of IS infiltration," The Jakarta Post, 6 Juli 2017.

Beech, Hannah. "Myanmar's radicalized Rohingnya," The New York Times International, 19 September 2017.

"BNN: Ridho Tak Akan Direhabilitasi," Kompas, 29 Maret 2017.

Budiari, Indra." 6 countries to discuss terrorism," The Jakarta Post, 22 Juli 2017.

"Cegah Teroris, Polisi dan TNI Siaga di Perbatasan," Suara Pembaruan, 31 Mei 2017.

Chairunnisa, Ninis. "Kombatan ISIS Filipina Berpotensi Masuk Indonesia," Koran Tempo, 8 Juni 2017.

Cheong, Danson. "ISIS posts video of first S'porean fighter in Syria," The Jakarta Post, 25 September 2017.

- "Terrorist mark two Singapore spots as targets last years," The Jakarta Post, 3 Juni 2017.

"Dana WNI ke Marawi Diselidiki," Kompas, 12 Agustus 2017.

Dancel, Raul.”Terrorism in Southeast Asia: 3 ASEAN countries to work on action plan," The Straits Times, 23 Juni 2017.

"Datang Bergelombang, Suku Uighurs Lantas Bergabung dengan Santoso," Koran Jakarta, 28 April 2016.

Douglas, Jeremy and Joseph Gyte. "ASEAN's terrorism threat calls for urgent actions." The Jakarta Post, 16 Februari 2017.

"Empat WNI Tewas di Marawi," Manado Post, 3 Juni 2017.

Hookway, James."ISIS Sinks Teeth Into Philippines," The Wall Street Journal, 15 Juni 2017. 
"Indonesia Undang 5 Negara Bahas Konflik di Marawi," Media Indonesia, 27 Juli 2017.

"ISIS Malaysia Ingin Jihad ke Myanmar," Suara Pembaruan, 19 September 2017.

Ismail, Faisal,"Khilafah dalam Perspektif Sejarah," Koran Sindo, 8 Mei 2017.

Hendra,Yose. "Belasan Warga Sumbar Terlibat Jaringan Terorisme," Media Indonesia, 9 Agustus 2017.

"KBRI di Filipina akan Pulangkan 16 WNI," Media Indonesia, 30 Mei 2017.

"Kerja Sama Antiterorisme Harus Lintas Negara," Kompas,3 Juni 2017.

"KBRI di Filipina akan Pulangkan 16 WNI," Media Indonesia, 30 Mei 2017.

"Kombatan Indonesia di Marawi Anggota JAD," Koran Tempo, 8 Juni 2017.

"Konflik Marawi: Asia Tenggara Hadapi Ancaman Baru," Suara Pembaruan, 22-23 Juli 2017.

"Konflik Marawi: 38 WNI Terlibat Terorisme di Filipina," Koran Jakarta, 3-4 Juni 2017.

"Kota Marawi, Tak Ada Lagi Kedamaian," Kompas, 31 Mei 2017.

"Krisis Mindanao: Kehadiran Milisi Asing Bukti Ancaman NIIS," Kompas, 2 Juni 2017.

"Krisis Mindanao: Militer Filipina Gencarkan Serangan," Kompas, 18 Juni 2017.

Leder, Edith M."ISIS on defensive in conflict areas but adapting: UN chief," The Jakarta Post, 8 Februari 2017.

Loppies, Sukma."AS Pasok Senjata ke Filipina," Koran Tempo, 6 Juni 2017.

. "Milisi Asing Ikut Berperang di Marawi," Koran Tempo, 3-4 Juni 2017.

"MA Filipina Dukung Duterte," Kompas, 5 Juli 2017.

"Malaysia Akan Kirim Bantuan Kemanusiaan ke Marawi," Rakyat Merdeka, 8 Juli 2017.

"Malaysia Siaga Tinggi dari Pelarian Milisi ISIS ," Suara Pembaruan, 11 Juli 2017.
"Militan ISIS Masih Kuasai 1.500 Bangunan di Marawi," Suara Pembaruan, 4 Juli 2017.

"Militan Marawi Kian Terpojok," Koran Sindo, 23 Juni 2017.

"NIIS Bisa Menyerang Balik," Kompas, 10 Juli 2017.

Nursyabani, Fira."Tiga Negara Bahas Marawi," Republika, 21 Juni 2017.

Otto, Ben. "Combative Duterte Gets an Opponent He Didn't Want," The Wall Street Journal," 30 Juni- 2 Juli, 2017.

"Philippines Islamist Attack Second Town," The Wall Stree Journal, 22 Juni 2017.

Paddock, Richard C. "Duterte ignored rise of ISIS," The New York Times International, June 13, 2017.

Paddock, Richard C. "Influence of ISIS in Southeast Asia attacks," The New York Times International Edition, 29 Mei 2017.

"Parlemen Filipina Desak Aset Maute Dibekukan," Koran Tempo, 13 Juni 2017.

"Patroli Batas Sulut-Filipina Makin Ketat," Manado Post, 2 Juni 2017.

"Penanggulangan Militan: RI Ajak 5 Negara Gempur ISIS Marawi,” Koran Jakarta, 14 Juni 2017.

"Penilaian Eks WNI Milisi Mindanao: ISIS Tidak Akan Bisa Bercokol di Indonesia," Rakyat Merdeka, 17 Juni 2017.

"Perang Masuki Bulan Ketiga," Kompas, 24 Juli 2017.

Ruslan Sangadji,"No more foreigner to join MIT terror group: Police," The Jakarta Post, 4 April 2016.

."Chinese Uighurss key players in IS-linked MIT: Police," The Jakarta Post, 7 Januari 2016.

."No more foreigner to join MIT terror group: Police," The Jakarta Post, 4 April 2016. 
."Chinese govt offers assistance to identify Uighurs joining MIT," The Jakarta Post, 28 Maret 2016.

.Police hunting IS leader Santoso to launch new operation," The Jakarta Post, 11 Januari 2016.

."Chinese Uighurss key players in IS-linked MIT: Police,” The Jakarta Post, 7 Januari 2016.

Salim, Tama. "Indonesia calls trilateral meeting on counterterrorism," The Jakarta Post, 21 Juni 2017.

Santi, Natalia."Militer Filipina Temukan Jasad Milisi Asal Indonesia," Koran Tempo, 5 Juli 2017.

Sapiie, Marguerite Afra and Haeril Halim, "Report warns of Marawi battle fallout," The Jakarta Post, 22 Juli 2017.

"Satu Saudara Maute Ditangkap," Kompas, 16 Juni 2107.

"Sel NIIS Ada di 16 Daerah," Kompas, 16 Juni 2016.

"Singapura Usir WNI Teradikalisasi," Media Indonesia, 6 Juli 2017.

Suara Pembaruan, 16 Juni 2017.

"Sulut Aman, Jangan Jadi Penyebar Hoax," Manado Post, 10 Juni 2017.

“TNI Bangun Pusat Komando," Republika, 21 Juni 2017.

"Teror Lintas Negara," Koran Tempo, 29 Mei 2017

"TNI Waspadai Ancaman ISIS," Koran Tempo, 10 Nopember 2016.

Trofimov, Yaroslav."After Mosul, Faraway ISIS 'Provinces' Fight On," The Wall Street Journal, 21-23 Juli 2017.

Kompas, 17 Mei 2016.

Watts, Jake Maxwell. "Philippines Stumbles in War on Militants," The Wall Street Journal, 2-4 Juni 2017.
,"Clashes Escalate in Southern Philippines," The Wall Street Journal," 25 Mei 2017.

Widadio, Nicky Aulia."38 WNI Terlibat Teror di Marawi," Media Indonesia, 3 Juni 2017.

Zamzami, Fitriyan."Patroli Indonesia-Filipina Diharap Halau ISIS," Republika, 5 Juli 2017.

"17 WNI Dievakuasi dari Marawi," Koran Sindo, 31 Mei 2017.

“8 Teroris Ditangkap," Manado Post, 9 Juni 2107.

\section{Portal}

Samosir, Hanna Azarya. "Indonesia dan China Kerjasama Bendung Arus Militan Uighurs,"CNN Indonesia.com, 06/01/2016, diakses pada 16 Nopember 2016

\section{Daftar Wawancara}

Wawancara dengan Sidney Jones, analis keamanan dan terorisme internasional dan Direktur the Institute for Policy and Analysis of Conflict (IPAC), pada 4 April 2016 di Jakarta.

Wawancara dengan Kol. Laut (Pelaut) I. Putu Daryatna, Asisten Perencanaan Lantamal VII,I pada 4 April 2016 di Jakarta.

Wawancara dengan Kol. Laut (Pelaut) A.M. Susanto, S.W. Asisten Operasi Lantamal VIII pada 11 Mei 2016 di Manado.

Wawancara dengan Kol. Laut (Pelaut) Ivong Wibowo, Asisten Intelijen Lantamal VII,I pada 11 Mei 2016 di Manado.

Wawancara dengan Letkol. Laut (KH) F.V. Yakobus, Danlanal Kabupaten Talaud, pada 11 Mei 2016 di di Kabupaten Melonguane. Manado.

Wawancara dengan Denny Sondakh, Kabag Hukum Pemerintah Kabupaten Kepulauan Talaud, pada 11 Mei 2016 di Manado.

Wawancara dengan Kompol Malsukri, Kasubbag Produk Bagian Analisa Ditintelpam Polda Sulawesi Tengah, pada 24 Mei 2016 di Palu. 
Wawancara dengan Kompol Fadly, Kepala Koordinasi Sekretaris Pimpinan Polda Sulawesi Tengah, pada 24 Mei 2016 di Palu.

Wawancara dengan AKBP Saiful, Kepala SubDirektorat II Polda Sulawesi Tengah, pada 24 Mei 2016 di Palu.

Wawancara dengan Kompol Sapruddin, Kepala Subbag Penmin/d.h. Intelpam Polda Sulawesi Tengah, pada 24 Mei 2016 di Palu.

Wawancara dengan Letkol (Inf) Adrian Susanto, Kepala Staf Korem 132/Tadulako, pada 25 Mei 2016 di Palu.

Wawancara dengan Dr. Muhammad Khairil, SAg, MSi, Ketua Prodi Komunikasi dan Pengajar dan Peneliti Terorisme dari Universitas Tadulako, pada 26 Mei 2016 di Palu.

Wawancara dengan Nasir Abbas, mantan Ketua Mantili III JI, pasca-FGD tentang amandemen RUU Tindak Pidana Terorisme dan Penanganan Korban pada 4 Nopember 2016 di Banten.

Wawancara dengan 2 Perwira Densus 88, Anggota Tm Pemerintah yang menghadiri Pembahasan Amandemen RUU TindakPidana Terorisme, pada 30 Maret 2017 di Jakarta.

Wawancara dengan Sidney Jones, analis keamanan dan terorisme internasional, Direktur The Institute for Policy and Analysis of Conflict (IPAC), pada 26 April 2017 di Jakarta (dengan jawaban secara tertulis).

Wawancara dengan Letkol Maftukin, Danlanal Melonguane, pada 4 Juni 2017 di Miangas.

Wawancara dengan Mayor (Inf) S.W. Panaha, Kodim Santiago, Melonguane, pada 4 Juni 2017 di Miangas.
Wawancara dengan Sersan Kepala Edgar Catamco, anggota AL Filipina penghubung Kerja Sama Perbatasan RI-Filipina, pada 4 Juni 2017 di Miangas.

Wawancara dengan 3 prajurit Koramil Miangas, pada 5 Juni 2017 di Miangas.

Wawancara dengan Bripka Sandro Tale, Kaunit Reskrim Polsek Miangas, pada 6 Juni 2017 di Miangas.

Wawancara dengan Serka Buntomo Sampe, prajurit Posal Miangas, pada 6 Juni 2017 di Miangas.

Wawancara dengan Kenangan Lupa, Kepala Kantor Imigrasi Miangas, pada 7 Juni 2017 di Miangas.

Wawancara dengan Anius Wudu, Tokoh Masyarakat warga Miangas, pada 8 Juni 2017 di Miangas.

Wawancara dengan Gerson Pogo, Kepala Kantor Bea-Cukai Miangas, pada 8 Juni 2017 di Miangas.

Wawancara dengan Pendeta Anugerah, Pendeta Kristen putera daerah Miangas, pada 9 Juni 2017 di Miangas.

Wawancara dengan Kapten Ali S.W, Bagian Intelijen Lantamal XIII Tarakan, Polres Tarakan, Provinsi Kalimantan Utara, pada 2 Agustus 2017.

Wawancara dengan AKP Joko, Bagian Intelkam, Polres Tarakan, di Tarakan, Provinsi Kalimantan Utara, pada 2 Agustus 2017.

Wawancara dengan Letkol (L) Pelaut Ari Aryono, Danlanal Nunukan di Mako Lanal Nunukan, pada 3 Agustus 2017. 